
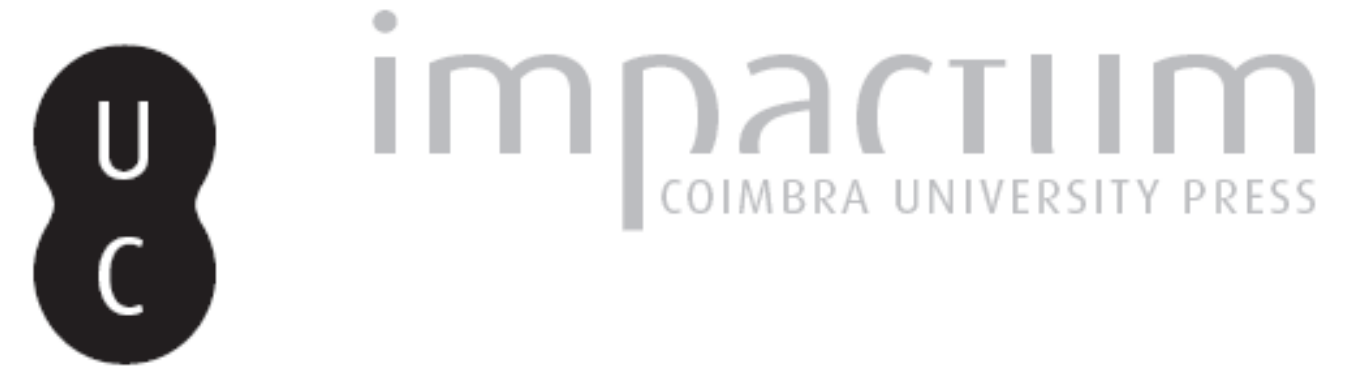

\title{
Globalização, mestiçagens e diálogo intercultural
}

\author{
Autor(es): $\quad$ André, João Maria
}

Publicado por: Imprensa da Universidade de Coimbra

URL persistente:

URl:http://hdl.handle.net/10316.2/43692

DOI:

DOI:https://doi.org/10.14195/2183-8925_25_1

Accessed : $\quad$ 26-Apr-2023 05:22:17

A navegação consulta e descarregamento dos títulos inseridos nas Bibliotecas Digitais UC Digitalis, UC Pombalina e UC Impactum, pressupõem a aceitação plena e sem reservas dos Termos e Condições de Uso destas Bibliotecas Digitais, disponíveis em https://digitalis.uc.pt/pt-pt/termos.

Conforme exposto nos referidos Termos e Condições de Uso, o descarregamento de títulos de acesso restrito requer uma licença válida de autorização devendo o utilizador aceder ao(s) documento(s) a partir de um endereço de IP da instituição detentora da supramencionada licença.

Ao utilizador é apenas permitido o descarregamento para uso pessoal, pelo que o emprego do(s) título(s) descarregado(s) para outro fim, designadamente comercial, carece de autorização do respetivo autor ou editor da obra.

Na medida em que todas as obras da UC Digitalis se encontram protegidas pelo Código do Direito de Autor e Direitos Conexos e demais legislação aplicável, toda a cópia, parcial ou total, deste documento, nos casos em que é legalmente admitida, deverá conter ou fazer-se acompanhar por este aviso.

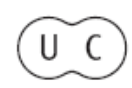



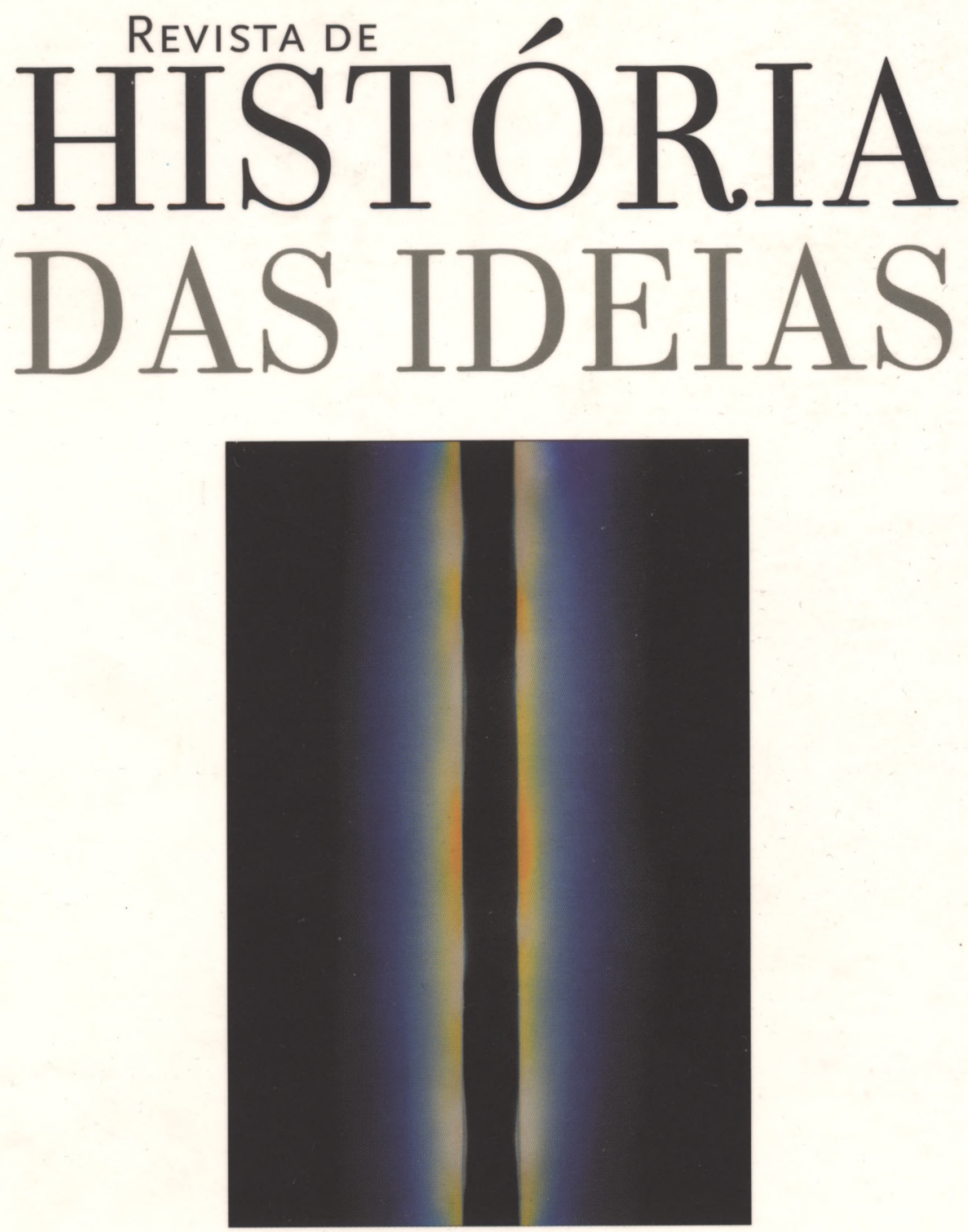

TOLERÂNCIAS, INTOLERÂNCIAS

\author{
Volume 25, 2004
}

INSTITUTO DE HISTÓRIA E TEORIA DAS IDEIAS

Faculdade de Letras da Universidade de CoImbra 


\section{GLOBALIZAÇÃO, MESTIÇAGENS E DIÁLOGO INTERCULTURAL}

\section{Introdução}

Quando entramos no século XXI, cruzam-se nos nossos gestos a memória de outros gestos, mistura-se na nossa língua a Babel de outras línguas, sobrepõem-se na nossa pele múltiplos tecidos de outras peles, como páginas reunidas de livros em movimento. Querendo pensar-nos na nossa identidade, perante a tentação do sonho de um sujeito, pessoa ou substância, que replicaria, nas estruturas individuais ou colectivas, os absolutos sujeitos do século XIX, depressa nos damos conta de que essa identidade se constitui de uma pluralidade de identidades em fluxo contínuo, rede comunicativa, teia de relações, num labirinto de referências cujo sentido mergulha em raízes dificilmente perceptíveis na pele da cultura que constitui a capa mais visível, superficial e tecnologicamente homogeneizada do mundo em que vivemos. Ínfimos pontos nodais do planeta chamado Terra, vemo-nos a viver em vizinhança total nesta aldeia global, numa intersecção, feita muitas vezes de diálogos, mas construída também sobre rasuras, esquecimentos e destruições, do tempo e da história, dos tempos e das histórias.

É neste horizonte que nos sentimos interpelados para uma reflexão sobre globalização, mestiçagens e diálogo intercultural, atentos ao que efectivamente está envolvido neste jogo conceptual, já que a pluralidade característica dos objectos em análise inscreve-se também, sob a forma

\footnotetext{
* Faculdade de Letras da Universidade de Coimbra.
} 
de pluralismo semântico ou até de ambiguidade categorial, nas noções que utilizamos para exprimir esta realidade movediça em que nos situamos. De facto, tanto globalização como mestiçagem são conceitos que, pela sua multidimensionalidade e pela multidimensionalidade dos fenómenos que traduzem, podem dizer coisas diferentes, nem sempre facilmente integráveis, e muito menos valorizáveis no mesmo sentido nas suas implicações societais e nas suas configurações dos sujeitos a que dizem respeito. Porque se, como veremos, há uma globalização que pode passar pela tradução em sociedade do conceito de solidariedade, como forma ecoética de o homem se situar no mundo, há uma outra globalização de rapina, que dá forma e conteúdo ao conceito de exploração dos países da periferia pelos países do centro e dos países do hemisfério sul pelos países do hemisfério norte. De modo idêntico, se há mestiçagens que se constituem com base no encontro e no diálogo, outras há que resultam da conquista, da violação, do sangue e do sémen misturados num projecto de domínio que é simultaneamente, não poucas vezes, um projecto de exterminação das diferenças e de homogeneização da alteridade. Por outro lado, falar de mestiçagem a propósito de globalização, de multiculturalismo e de interculturalidade, ou seja, inscrever uma reflexão sobre a mestiçagem no quadro da Filosofia e da Antropologia da Cultura é transpor uma categoria do chão em que originariamente emergiu, o campo disciplinar da biologia, para um outro campo que se lhe sobrepõe, o campo disciplinar da cultura, ou seja, é operar uma transposição conceptual que se traduz naquilo que habitualmente designamos como metáfora. Uma metáfora é uma expressão que diz algo mais para além (meta) do que diz, mas di-lo precisamente enraizada no chão discursivo em que o diz e em que se situa o respectivo referente, já que, como refere M. B. Pereira, comentando a noção de metáfora de P. Ricoeur, "a experiência que a metáfora pretende dizer, é a presença inarticulada de um excesso de sentido, cuja dinâmica arranca os significados já constituídos da sua situação ordinária e os transfere para um novo campo referencial"(1). Mas se, como diz o próprio Paul Ricoeur, "a metáfora é viva, ao inscrever o impulso da imaginação num 'pensar mais' ao nível do conceito"(2),

(1) M. B. Pereira, "Introdução à tradução portuguesa de Metáfora Viva de Paul Ricoeur", Porto, Res, 1983, p. XXXVII.

(2) Cf. Paul Ricoeur, La métaphore vive, Paris, Les Éditions du Seuil, p. 384. 
também se deve ter em conta o risco inerente à transgressão que opera, na medida em que pode transpor para o novo campo discursivo elementos semânticos que, em vez de um potencial de abertura, se podem transformar num potencial de redução da inteligibilidade dos fenómenos que, com a metáfora, se pretendem conceptualizar. Assim, a par do valor heurístico da metáfora, há que estar atento aos seus limites, para não perverter o campo que com ela se visa abrir. Ora, se as culturas, em certo sentido, se podem considerar como metáforas do real, em que se cruza a natureza com a sociedade, também a mestiçagem se pode considerar como uma metáfora das culturas, desde que se não transponha para o cruzamento das culturas um certo biologismo que seria redutor da sua riqueza semântica, tal como se não transpõe para o conceito de cultura o "fisicalismo" próprio da sua raiz etimológica. Assim, se tivermos em conta o carácter metafórico da mestiçagem, poderemos, com alguma abertura heurística e com alguma fecundidade hermenêutica, cruzar com ela os fenómenos da globalização, do multiculturalismo e da interculturalidade, considerando-os, também com as devidas cautelas, como diferentes metáforas da própria mestiçagem, implicando cada uma delas projectos valoriais e societais distintos.

Mas a pluralidade de sentidos para que remetem conceitos como globalização e mestiçagem não diz apenas respeito à sua origem ou à sua configuração actual, mas também às suas diferentes expressões histórico-temporais. Se é certo que a globalização tem hoje marcas específicas, é também verdade que algumas das características inerentes a esse fenómeno são também inerentes a outros fenómenos que se desenvolvem já há alguns séculos e que constituem, inclusivamente, um núcleo incontornável da nossa memória histórica, tal como a mestiçagem, se é, em certo sentido, capa e pele da cultura e das culturas da actualidade, foi sempre uma realidade, por vezes tragicamente vivida, quando movimentos migratórios ou expansionistas produziram o cruzamento de etnias diferentes, peles de cor diferente, diferentes árvores, diferentes sonhos e diferentes utopias. No nosso percurso histórico, concretamente, é impossível dissociar a globalização que sofremos hoje, como país que, de certo modo, se situa na periferia do sistema-mundo actual, de uma outra globalização que fizemos há cinco ou seis séculos, tal como não é possível deixar de recuperar a memória da mestiçagem a que essa outra globalização deu origem para pensar a mestiçagem com que hoje nos vemos, voluntária ou involuntariamente e consciente ou inconsciente- 
mente, coloridos. Não é, pois, inofensiva, esta aproximação entre o fenómeno da mestiçagem e o fenómeno da globalização. Ela prende-se com a tese central que gostaria de esboçar e apresentar num convite ao seu posterior aprofundamento e à sua indispensável justificação. Formulá-la-ia nos seguintes termos: se é verdade que a história não se repete, é também verdade que, na história, há mecanismos e processos que constituem réplicas ou sucedâneos de processos e mecanismos anteriores, embora com novas configurações e novas consequências, sendo um deles a mundialização, com a correspondente mestiçagem e homogeneização que lhe é inerente; e se há seis séculos nos contámos entre os seus principais agentes, contamo-nos hoje entre alguns dos seus mais significativos pacientes e, por esse motivo, é muito o que temos a aprender com os herdeiros das primeiras vítimas de anteriores mestiçagens e de anteriores globalizações e com a filosofia que, do lado dessas vítimas, se tem vindo a construir como o outro rosto ou a outra mensagem do progresso: uma filosofia intercultural, assente no diálogo entre as culturas e no potencial crítico de uma ética da libertação. Procurarei caminhar para esta tese, começando por uma especificação de alguns pressupostos epistemológicos e antropológicos para a compreensão da mestiçagem e do multiculturalismo no quadro da globalização, a que se seguirá a apresentação de um conjunto de traços que nos ajudam a definir o horizonte desta globalização que caracteriza o tempo actual. Poderemos assim problematizar, por um lado, o conceito de mestiçagem, na bipolaridade de algumas das suas formas de realização, para, por outro lado, a partir da noção de mestiçagem em profundidade, fazermos a sua articulação com o projecto de um diálogo intercultural que transforma o confronto em encontro e a tolerância em hospedagem do outro e no outro através da assunção das culturas como habitação e morada da solidariedade, da justiça e do corpo plural da alegria.

\section{Pressupostos epistemológicos e antropológicos}

Antes de abordar, de um modo mais pormenorizado, a forma como se pode passar do multiculturalismo ao diálogo intercultural, impõe-se, naturalmente, uma passagem por alguns dos pressupostos epistemológicos e antropológicos que nos permitem um acesso ao equacionamento da mestiçagem no quadro da globalização. 
Quer se parta do fenómeno da mestiçagem, quer se parta do fenómeno da globalização, somos, no contexto da reflexão que aqui ensaiamos, permanentemente remetidos para o conceito-chave de cultura, tanto na sua articulação com o conceito de homem, como na sua articulação com o conceito de identidade, já que aquilo de que se trata, em última análise, é de perceber o homem na sua identidade cultural. Mas a percepção do homem na sua identidade cultural no contexto do multiculturalismo, ou seja, no contexto de uma sociedade marcada pela coexistência, no seu seio, de uma multiplicidade de culturas que podem ter a sua raiz numa diversidade étnica, numa pluralidade de nacionalidades, numa diferença entre religiões ou ainda, entre outros factores, numa heterogeneidade de estilos de vida por grupos sociais distintos, exige a superação de um conjunto de traços epistemológicos que foram caracterizando, ao longo dos últimos séculos, a forma dominante da racionalidade moderna e que se mostram insuficientes para uma inteligibilidade adequada da sociedade plural e em movimento que é a nossa. Se alguns desses traços têm a sua origem na configuração lógica do pensamento definida pelos princípios fundamentais do organon aristotélico, outra parte muito significativa foi sendo acrescentada a partir da definição do saber como poder e da sua sobredeterminação por uma visão unidimensional do progresso que se foi sedimentando ao longo da Modernidade.

Enumeraria o direccionamento epistemológico adequado à compreensão da realidade social suposta pelo multiculturalismo e pela mestiçagem a partir de um conjunto de alternativas, visando colocar em relevo as características paradigmáticas que urge superar. Trata-se, assim, de postular uma epistemologia dinâmica versus uma epistemologia essencialista e substancialista, uma epistemologia do complexo versus uma epistemologia do simples, uma epistemologia do tempo contraditório versus uma epistemologia do tempo linear, uma epistemologia dialógica versus uma epistemologia monológica, uma epistemologia idiográfica versus uma epistemologia nomotética e uma epistemologia ecológica versus uma epistemologia tecnológica. Epistemologia de algum modo essencialista e substancialista como também centrada na simplicidade é, em certa medida, a epistemologia aristotélica, assente num conceito de substância entendida como suporte de atributos ou acidentes, definida pela sua essência captada na forma que lhe dá a sua universalidade, como o é também a epistemologia cartesiana, que se projecta, no seu ideal de clareza, rigor e evidência, como um regresso às naturezas 
simples, unidades irredutíveis de todo o saber, de toda a representação e da realidade que nela se representa. Um conhecimento construído a partir de uma tal epistemologia é, obviamente, incapaz de captar uma realidade movente e relacional, complexa na sua estruturação multidimensional, como é a realidade da cultura e como é também, inclusivamente, a própria realidade humana, tanto sob o ponto de vista do indivíduo, como sob o ponto de vista da sociedade. Mas, além de substancialista, essencialista e simplificadora, a epistemologia tradicional, aplicada à história e ao desenvolvimento das sociedades humanas, é também uma epistemologia do tempo linear, que pensou sempre a cultura a partir do conceito de uma óptica evolucionista, marcada pelo processo do caos para a ordem. Ora tanto a mestiçagem, desde as suas primeiras formas mais explícitas no século XVI, como o multiculturalismo, nas suas figuras actuais, são fenómenos que desafiam essa concepção linear e uniforme do tempo, pois, como diz Gruzinski, "ao reunir bruscamente humanidades desde há muito separadas, a irrupção das misturas sacode a representação de uma evolução única do devir histórico e ilumina bifurcações, travessias e impasses que somos obrigados a ter em conta"(3). Por outras palavras, se o tempo dos vencedores não é o mesmo do tempo dos vencidos, a pele que resulta da mistura de uns e outros obriga a uma complexidade narrativa feita de uma dialéctica temporal capaz de exprimir saltos simultâneos no tempo como buracos no tempo, cujo movimento, omnidireccional, não é centrífugo nem centrípeto pelo simples facto de que não tem um tempo absoluto a partir do qual possa ser lido. Neste contexto, a imagem da desordem sobrepõe-se à imagem da ordem tão privilegiada pela epistemologia cartesiana. Mas não menos importante é a dimensão dialógica de uma epistemologia multicultural na sua contraposição à dimensão monológica de uma epistemologia monocultural, porque esta, caracterizando-se por um certo dogmatismo, por um marcado objectivismo, por um acentuado realismo e por uma pretensa neutralidade axiológica e afectiva, com a redução do sujeito às suas funções cognitivas e a desvalorização dos factores simbólicos da vida colectiva, vê-se incapacitada de atender à diferença e à alteridade mais respeitadas por uma epistemologia multicultural em que o conhecimento, pressupondo uma atitude dialógica, é perspectivado como uma

\footnotetext{
(3) Serge Gruzinski, La pensée métisse, Paris, Fayard, 1999, p. 53.
} 
construção social, sublinhando-se, pois, o carácter conjectural e situado de toda a interpretação, a relatividade da verdade e dos juízos de valor dento dos quadros culturais em que se inserem e a dimensão política inerente a toda a apropriação cognitiva do real. Todo o eurocentrismo ou etnocentrismo cognitivo e axiológico repousa, em última instância, numa epistemologia monocultural e na absolutização dos seus critérios de verdade ${ }^{(4)}$. Entretanto, dado que se trata de pensar uma forma de acesso epistemológico e metodológico a uma realidade marcada pela diferença e pela singularidade, não na sua irredutibilidade, mas na forma como estrutura uma relação constitutiva com o mundo e com os outros, parece interessante recuperar duas categorias que Windelband, no final do século XIX, contrapôs, para reclamar a especificidade das ciências do espírito: o procedimento idiográfico, que se entende como um estudo descritivo do individual e o procedimento nomotético que visa uma subsunção dos fenómenos individuais sob leis universais ${ }^{(5)}$. Se no primeiro caso se procede de forma ascendente, sem padrão de generalização ou estandardização, no segundo caso procede-se de forma descendente, agrupando o diferente com base num critério unificador, o que introduz variações de percepção que podem distorcer uma visão adequada da diferença no contexto da realidade humana e do dinamismo cultural ${ }^{(6)}$. Finalmente, parece-nos indispensável contrapor os princípios do que poderíamos chamar uma epistemologia tecnológica ou instrumental aos

(4) Cf. A. Semprini, Le multiculturalisme, Paris, PUF, 1997, pp. 57-63. Também a este propósito e sobre as respectivas implicações de uma hermenêutica crítica, cf. João Maria André, "Pluralidade de crenças e diferença de culturas. Dos fundamentos filosóficos do ecumenismo de Nicolau de Cusa aos princípios actuais de uma educação intercultural", in A. Borges, A. P. Pita, J. M. André, (Coord.), Diálogo e tempo. Homenagem a Miguel Baptista Pereira, Porto, Fund. Eng. António de Almeida, 2000, pp. 488-490.

(5) Cf. Windelband, "Historia y Ciencia de la Naturaleza [Discurso rectoral en la Universidad de Estrasburgo]", in idem, Preludios Filosóficos, trad. de W. Roces, Buenos Aires, Santiago Rueda Editor, pp. 311-328.

(6) Sobre a importância das ordenações nomotéticas ou idiográficas para a construção da diferença no estudo do fenómeno do multiculturalismo, cf. F. Javier García Castaño, Antolín Granados Martínez, e Rafael A. Pulido Moyano, "Reflexiones en diversos ámbitos de construcción de la diferencia", in F. Javier García Castaño y Antolín Granados Martínez, (Eds.), Lecturas para educación intercultural, Madrid, Editorial Trotta, 1999, pp. 21-23. 
princípios de uma epistemologia ecológica, não no sentido primário e imediato do termo, de uma epistemologia atenta à natureza e à vida no seu meio envolvente (o que também, diga-se de passagem, não deixa de ser pertinente), mas no sentido em que transfere para a inteligibilidade do seu objecto princípios e jogos processuais idênticos aos que estão implicados numa compreensão dos ecossistemas naturais. Dessa contraposição decorreria uma superação do dualismo radical entre sujeito e objecto de conhecimento, a substituição do primado dado à análise por um olhar mais holístico e abrangente, a passagem a primeiro plano da categoria de relação versus a categoria de coisa e sobretudo a assunção de uma perspectiva ecossistémica mais adequada à compreensão das culturas e da sua evolução nas sociedades humanas e nos seus contextos naturais, a partir da forma como mutuamente se alimentam e interagem num movimento pluridireccional.

Claro que a importância e a justeza dos pressupostos epistemológicos acabados de enunciar tornam-se muito mais evidentes quando os articulamos com alguns dos pressupostos antropológicos que o facto do multiculturalismo e o projecto de uma dinâmica intercultural reclamam como pano de fundo para a sua afirmação. Em primeiro lugar, uma concepção dinâmica (e, ao mesmo tempo, plural e dialógica), não só de cultura, mas também de identidade. Os fenómenos do multiculturalismo e da mestiçagem cultural passar-nos-ão completamente ao lado se não conseguirmos superar a tradicional concepção de cultura como sistema mais ou menos estável de traços, heranças, usos e objectos que definem a memória identitária de um grupo ${ }^{(7)}$. Se, como refere Gruzinski, "para apreender as misturas, é necessário começar por desconfiar do termo 'cultura', usado até ao limite por gerações de antropólogos, sociólogos e historiadores", por remeter para a crença na existência desse "conjunto complexo, totalidade coerente, estável, de contornos tangíveis, capaz de condicionar os comportamentos" ${ }^{\prime \prime(8)}$, é também necessário começar por

\footnotetext{
(7) Para uma breve visão panorâmica de algumas das noções de cultura, numa perspectiva ainda estática, presentes em alguns dos autores que se debruçaram sobre o fenómeno do multiculturalismo, cf. F. Javier García Castaño, Rafael A. Pulido Moyano e Ángel Montes del Castillo, "La educación multicultural y el concepto de cultura", in F. Javier García Castaño y Antolín Granados Martínez, (Eds.), ob. cit., pp. 65-68.

(8) Cf. S. Gruzinski, ob. cit., p. 45.
} 
questionar, em termos antropológicos, sociológicos e políticos, o próprio conceito de identidade, superando a sua matriz liberal anglo-saxónica que vê a construção da identidade como um processo de auto-expansão e auto-desenvolvimento do indivíduo. É essa superação que propõe Ch. Taylor, segundo o qual "a descoberta da minha identidade não significa que eu me dedique a ela sozinho, mas sim que eu a negoceie, em parte abertamente, em parte interiormente, com os outros", o que permite considerar que "a minha identidade depende, decisivamente, das minhas relações dialógicas com os outros"(9), em cuja base assenta a conhecida política do reconhecimento que este autor reclama como resposta ao problema do multiculturalismo. Uma análise crítica da forma de desenvolvimento tanto dos indivíduos como dos grupos mostra que a respectiva identidade e o que lhe dá visibilidade sob a forma de cultura é um processo de interacções, permanentemente em devir, em que a diferença e a alteridade constituem sempre o pólo dialógico de constituição do eu e da sua autenticidade, até porque, como também refere Abadallah-Pretceille, quando se procura captar a noção de cultura, não tanto a partir dos seus traços específicos, mas das suas condições de produção e de emergência e também dos processos de aculturação (não reduzindo este fenómeno aos jogos verticais de poder e de dominação, mas alargando-o aos jogos horizontais de evolução e adaptação), as culturas são "uma tensão entre, por um lado, a dobra e o fechamento (le repli et l'enfermement) e, por outro lado, a abertura e a mestiçagem (l'ouverture et le métisssage)"(10). Daí a conclusão de que "cultura e identidade se declinam doravante no plural", dada a multiplicidade de culturas com as quais se mantém uma relação de pertença, e dados os ajustamentos, os conflitos, as contradições e os disfuncionamentos em que se forja a identidade e que obrigam a ver o indivíduo não apenas como o produto das suas inscrições e enraizamentos, mas também como autor, produtor e actor ${ }^{(11)}$. Cai, assim, a característica da unicidade e da homogeneidade,

(9) Ch. Taylor, "A política do reconhecimento", in Ch. Taylor et alii, Multiculturalismo. Examinando a política do reconhecimento, trad. de M. Machado, Lisboa, Instituto Piaget, 1998, p. 54.

(10) Martine Abdallah-Preteceille, L'éducation interculturelle, Paris, PUF, 1999, p. 13.

(11) Cf. idem, ibidem, pp. 10-15. 
como traço distintivo do que é uma cultura, passando a primeiro plano a ideia, sustentada por García Castaño, de que "o que propriamente constitui a cultura não é uma homogeneidade interna, mas a organização das diferenças internas" ${ }^{\prime 12)}$, organização essa que parece adquirir traços de homogeneidade quando nos afirmamos distintivamente perante outros, mas que é muito mais heterogénea quando nos pensamos a nós próprios na nossa riqueza e na nossa constitutiva pluralidade. Entretanto, importa ainda ter em conta que, se uma concepção estática e unitária de cultura deve ser superada, mal seria que tais características contaminassem, como chegaram a contaminar em alguns casos, a própria ideia de mestiçagem, a qual não pode senão ser vista no plural: o mestiço ou o crioulo são realidades intrinsecamente plurais, não podendo funcionar sequer como categorias para agrupar e classificar comodamente traços biológicos, psicológicos, sociológicos ou culturais de um determinado tipo de pessoas como se de um grupo homogéneo se tratasse, nivelando as diferenças e reduzindo-as a um confuso denominador comum ${ }^{(13)}$.

O segundo pressuposto que o multiculturalismo, a mestiçagem e o projecto da interculturalidade implicam prende-se com a necessidade de pensar a cultura não como uma realidade meramente intelectual ou espiritual, mas como uma realidade que tendo "corpo" e tendo "mundo" tem uma materialidade específica e implica uma relação peculiar com o seu território que não pode ser esquecida ou marginalizada. É porque se esquece esta particularidade (esquecimento que tem raízes muito antigas em todo o dualismo ocidental, que prolonga a dualidade corpo-alma, na dualidade natureza-espírito) que facilmente se incorre no deslize de esquecer as dimensões culturais da globalização, reduzindo-a a um fenómeno meramente económico ou tecnológico. Ora, mesmo falando exclusivamente da globalização neoliberal, que parece reclamar uma centração exclusiva na infraestrutura económica, o que acontece é que é exactamente a esse nível que ela retira corpo, espaço, território às culturas mais frágeis em termos da respectiva estrutura material. Raúl Fornet-Betancourt reforça significativamente esta componente ao afirmar

(12) F. Javier García Castaño, Rafael A. Pulido Moyano e Ángel Montes del Castillo, "La educación multicultural y el concepto de cultura", p. 70.

(13) Cf. Raúl Fornet-Betancourt, Transformación intercultural de la Filosofía, Bilbao, Desclée de Brouwer, 2001, p. 278. 
que "cultura não significa uma esfera abstracta, reservada à criação de valores 'espirituais', mas o processo concreto pelo qual uma comunidade humana determinada organiza a sua materialidade em ordem aos fins e valores que quer realizar"(14). Isto significa, por um lado, a clara rejeição de um processo de intimização das culturas, ou seja, da sua redução a uma mera vivência interior ${ }^{(15)}, e$, por outro lado, de uma forma positiva, a afirmação clara de uma concepção ecológica de cultura: toda a cultura tem o seu território, o seu mundo, o seu meio de desenvolvimento, de que se alimenta e que vai simultaneamente ajudando a configurar, num diálogo, dialéctico mas também dialógico, entre natureza e cultura ${ }^{(16)}$, incorporando não só o presente, mas também o passado condensado na memória e o futuro implícito nos projectos humanos. Como diz Miguel Baptista Pereira, reportando-se a esta concepção ecológica de cultura, "lugar ou habitat do homem não é apenas o espaço empírico imediato mas também a produção cultural nele inscrita por comunidades passadas, que o abriram a outros lugares e a espaços mais vastos e da qual ele se apropria pela corporeidade pessoal que lhe permite ser com outros corpos e tempos". Por isso, ainda segundo o mesmo autor, "a morada do homem rasga o futuro a partir do seu espaço de memória ao acolhimento do diferente e lugar de enriquecedora troca cultural"(17).

É por esse motivo que, como terceiro pressuposto para uma adequada compreensão do multiculturalismo e da mestiçagem, é necessária uma concepção mais narracional do que estrutural de cultura, já que herdando o carácter dinâmico do seu processo de emergência e de construção e incorporando a memória das interacções com os outros, não é tanto o sistema quanto a narrativa que melhor a exprime. Efectivamente, se, por um lado, é a narrativa que melhor dá conta da tensão entre inovação e tradição que é constitutiva de qualquer cultura, por outro lado, tendo em conta que, além disso, uma cultura é também a memória dos seus acontecimentos num desdobramento das páginas que os narram reencontrando os seus agentes e pacientes, muitas vezes sob a forma de

(14) Raúl Fornet-Betancourt, ob. cit., p. 181.

(15) Cf. idem, ibidem, p. 378.

(16) Cf. idem, ibidem, pp. 178-179.

(17) Miguel Baptista Pereira, "Alteridade, linguagem e globalização", Revista Filosófica de Coimbra, vol. XII/23, 2003, p. 5. 
vencedores e de vencidos, é também no registo biográfico (do indivíduo ou do grupo) que melhor se captam as expressões vivas da cultura. Daí que Enrique Dussel, na sequência de um texto notável e verdadeiramente antecipador de Paul Ricoeur publicado já em 1964, encontre no que este filósofo francês chama o núcleo ético-mítico das culturas a sede da sua singularidade civilizacional, nele se enraizando o seu poder criador ${ }^{(18)}$. Tal núcleo encontra-se, segundo Ricoeur, naquela "camada de imagens e símbolos que constituem as representações de base de um povo"(19). Através da forma narrativa, supera-se tanto a tentação da sistematização movida e sobredeterminada por uma lógica linear, quanto a tentação pós-moderna da fragmentação total que não chega a ultrapassar a visão do multiculturalismo como um simples mosaico de pedaços em sobreposição ou justaposição permanentes. Mas, além disso, respeita-se o carácter de situação ou acontecimento que está na base de todo o dinamismo cultural e implica-se a dimensão dramática inerente ao facto de toda a cultura ser sempre uma mise-en-scène do eu com os outros.

\section{O horizonte da globalização}

Partindo dos pressupostos epistemológicos e antropológicos acabados de enunciar, clarifiquemos agora o horizonte a partir do qual pretendemos articular a problemática do multiculturalismo com a mestiçagem tendo em vista a urgência de um diálogo intercultural como resposta a essa problemática. Esse horizonte é, naturalmente, o horizonte da globalização, mas, dada uma certa usura ou inflação deste termo no vocabulário da actualidade, gostaria de especificar um pouco mais de que fenómeno falo quando falo de globalização.

Claro que não é este o local para fazer um balanço das diversas noções de globalização que têm vindo a ser propostas por aqueles teóricos que mais se vêm destacando no aprofundamento e na abordagem crítica deste

(18) Cf. E. Dussel, "La globalización y las víctimas de la exclusión", in Raúl Fornet-Betancourt, (Ed.), Culturas y Poder. Interacción y asimetría entre las culturas en el contexto de la globalización, Bilbao, Desclée de Brouwer, 2003, p. 110.

(19) Paul Ricoeur, "Civilisation universelle et cultures nationales", in idem, Histoire et vérité, Paris, Éd. du Seuil, 1964, p. 296. 
fenómeno, desde a de Giddens, mais centrada na intercomunicação mundial ("intensificação das relações sociais mundiais que entrelaça localidades distantes de tal maneira que os eventos locais se modificam pelos eventos que ocorrem a muitas milhas de distância e vice-versa" ${ }^{\prime \prime 20)}$ ) ou a de McGrew ("intensificação da interconexão global" com a multiplicidade de signos implicados, no que se refere a bens, capital, relações sociais institucionais, desenvolvimento tecnológico e ideias em fluxo através de fronteiras territoriais $\left.{ }^{(21)}\right)$, passando pela definição de Robertson, que ressalta os fenómenos "tanto da compressão do mundo como da intensificação da consciência do mundo como um todo"(22), até à de Wallerstein, que considera a globalização indissociável do processo do sistema mundial capitalista e das suas tendências universalizantes ${ }^{(23)}$, sem esquecer a perspectiva de pré-abordagem desse fenómeno que transparece já do texto anteriormente citado de P. Ricoeur, onde tal tema aparece articulado fundamentalmente com a universalização de uma racionalidade científico-técnica expandida através de uma tecnocultura, são muitas e diversificadas as tentativas de esclarecer este fenómeno. De momento e com os objectivos com que esta reflexão é proposta, interessa-nos ressaltar quatro aspectos fundamentais: a sua pluridimensionalidade, alguns momentos da sua história, a metafísica e a antropologia que lhe estão subjacentes e as suas consequências para uma filosofia da cultura.

Quanto à sua pluridimensionalidade, basta-nos, de momento, rejeitar radicalmente a redução da globalização à sua dimensão meramente economicista e/ou tecnológica e a sua extensão à cultura e às culturas que com ela se vêem confrontadas ou por ela se vêem esmagadas. Não há dúvida de que a globalização aparece, na sua face mais visível, como um fenómeno económico, até pelo primado da economia e das grandes multinacionais na estruturação da vida e do próprio mundo como

(20) A. Giddens, Consecuencias de la Modernidad, trad. de A. Lizón Ramón, Madrid, Alianza Editorial, 2002, pp. 67-68.

(21) Apud J. Tomlinsen, Globalization and Culture, Cambridge, Polity Press, 1999, p. 2.

(22) R. Robertson, Globalization. Social Theory and Global Culture, London, Sage Publications, 1998, p. 8.

(23) Cf. I. Wallerstein, The Modern World-System, New York, Academic Press, 1989. 
sistema à escala global, e que tal configuração económica se repercute, de um modo imediato, no que se poderia designar como a tecnicização global, por um lado, e a vivência global dos problemas ecológicos, por outro $^{(24)}$. Mas a visibilidade dessas dimensões não pode levar ao esquecimento de outras, como a dimensão social, a dimensão cultural e a dimensão política ${ }^{(25)}$, havendo quem lhe acrescente, inclusivamente, a dimensão militar ${ }^{(26)}$. É a ideologia do neoliberalismo, também designada, neste contexto como globalismo ${ }^{(27)}$, que pretende fazer crer que a globalização é, sobretudo económico-financeira, e é numa clara demarcação dessa perspectiva que autores como Ulrich Beck referem as seis dimensões imprescindíveis para a sua caracterização: informática, ecológica, económico-financeira, de organização do trabalho, cultural e da sociedade civil $^{(28)}$. Mas se em vez de nos centrarmos nessas dimensões tentarmos perceber o que constitui o núcleo fundamental do projecto societário que lhe está subjacente, mais facilmente nos damos conta da natureza transversal desse núcleo e do modo como não há esfera que escape ao carácter imperialista e dominador desse projecto. É com esse intuito que Ulrich Teusch, apesar de analisar os diversos elementos que entram na constituição deste conceito, as suas causas pluridimensionais e a sua dinâmica própria de natureza dialéctica, prefere centrar-se no núcleo que constitui a chave para a leitura do seu significado: "a relativização dos limites, na medida em que esta relativização assume dimensões globais (ou potencial e tendencialmente globais) ou então ou se realiza num contexto global"(29). Nesta perspectiva, articula-se o conceito de globalização não apenas com um plano horizontal, mas também com um plano vertical, dizendo respeito não apenas às fronteiras geográficas

(24) Cf. U. Teusch, Was ist Globalisierung?, Darmstadt, Wissenschaftliche Buchgesellschaft, 2004, pp. 41-65.

(25) Cf. idem, ibidem, pp. 36-41.

(26) Cf. A. Giddens, Consecuencias de la Modernidad, pp. 72-79. Sobre os efeitos mais recentes da globalização militar e as suas encenações nomeadamente com a invasão do Iraque, cf. Francisco Louçã e Jorge Costa, A globalização armada. As aventuras de George Bush na Babilónia, Porto, Edições Afrontamento, 2004.

(27) Cf. Ulrich Beck, Qué es la Globalización, trad. de B. Moreno e Maria Rosa Morrás, Buenos Aires, Paidós, 2004, p. 26 ss.

(28) Cf. idem, ibidem, p. 40.

(29) Cf. U. Teusch, ob. cit., p. 86. 
e culturais, mas também aos actores e conjuntos de actores na sua hierarquização social e nas suas relações de poder e dominação( ${ }^{(30)}$.

Esta caracterização multidimensional e pluridireccional da globalização permite-nos reconhecer o seu carácter histórico, apresentando as marcas específicas com que se inscreve na nossa contemporaneidade, mas, neste contexto em que a cruzamos com a noção de mestiçagem, deve levar-nos, ao mesmo tempo, a ter em conta outros momentos da sua história que, sendo-lhe anteriores, não deixam de ajudar a compreender algumas das suas actuais características. Enrique Dussel faz recuar a história da constituição do que, na sequência de Wallerstein, ele chama World-System, nos seus primeiros estádios, às civilizações da Mesopotâmia e do Egipto (estádio I) às culturas do cavalo e do ferro, com os movimentos dos indo-europeus, dos medos e dos persas, dos hititas, dos gregos e dos latinos e ainda dos germanos no Norte da Europa (estádio II), à ponte Bizâncio-Bagdad, ao longo da Idade Média (estádio III), até chegar ao estádio mais recente, marcado por três grandes momentos, um que tem a Europa como centro e se desenvolve ao longo dos séculos $\mathrm{XV}$, XVI e seguintes (sob hegemonia espanhola e depois holandesa), outro correspondente à expansão do capitalismo industrial (sob hegemonia inglesa) e o último correspondente ao momento actual da globalização (sob hegemonia norte-americana) ${ }^{(31)}$. Se nos centrarmos nos momentos deste último estádio, damo-nos conta de que apresentam, cada um deles, características diversas (que fazem com que a globalização hoje tenha uma especificidade incontornável) mas partilham simultaneamente alguns traços indispensáveis para esta articulação que propomos entre globalização, multiculturalismo, mestiçagem e interculturalidade. É que o confronto de culturas e a mestiçagem propriamente dita não são uma prerrogativa deste estádio, mas constituem um traço essencial da expansão e de desfronteirização que se verifica desde o século $X V$, e, mais do que isso, partilham com esse momento a dinâmica do conflito, do processo dialéctico da inclusão/exclusão, com o cortejo de vítimas que lhe é inerente, partilhando também (ainda que de uma forma que o movimento neoliberal tenta ocultar) a dimensão cultural, outrora mais claramente colonizadora e agora não menos aculturadora, mas sob a roupagem do progresso científico-técnico-instrumental.

\footnotetext{
(30) Idem, ibidem, p. 87.

(31) Cf. E. Dussel, art. cit., pp. 113-119.
} 
De momento, mais do que explorar outras consequências ou outros aspectos da globalização, interessa-nos, no quadro desta reflexão, sublinhar os princípios metafísicos e antropológicos que a suportam, a fim de contrariar a interpretação de que o Sistema-mundo que nela se esboça tem uma configuração essencialmente comunicativo-material.

Diria assim, em primeiro lugar, que a globalização, nomeadamente a globalização neoliberal com que nos vemos confrontados nos tempos actuais, implica uma concepção metafísica, de ser mundo e de ser no mundo, implica uma concepção antropológica de ser humano e implica uma concepção de progresso e de filosofia da história. No que se refere à nova concepção metafísica, ela é marcada, em primeiro lugar, por aquilo que Marx, de uma forma intuitiva, percebeu como as características da "moderne Lebensgeschichte des Kapitals" e que, com Engels, no Manifesto do Partido Comunista, caracterizava nestes termos: "Mediante a exploração do mercado mundial, a burguesia deu um carácter cosmopolita à produção e ao consumo. [...] Em vez das antigas necessidades, satisfeitas com produtos nacionais, surgem necessidades novas, que reclamam para a sua satisfação, produtos dos países mais afastados e de climas mais diversificados.[...] Graças ao rápido aperfeiçoamento dos instrumentos de produção e do constante progresso dos meios de comunicação, a burguesia arrasta a corrente da civilização a todas as nações, até às mais bárbaras"(32). As previsões não podiam ser mais certeiras, devendo notar-se que Marx nem sequer sonhava com as actuais auto-estradas da comunicação... Interpretado este movimento de constituição do mundo numa investigação de natureza fenomenológica, ou seja, fazendo uma fenomenologia da globalização (que passa por uma fenomenologia do espírito da globalização) pode dizer-se que a metafísica do espírito neoliberal que a promove em termos económicos desenha claramente um horizonte de mundo e de relação do homem com o mundo e com a natureza marcada pela técnica, pelo cálculo, pela instrumentalização ${ }^{(33)}$, de tal maneira que, radicalizando a interpretação heideggeriana da Modernidade como "Die Zeit des Welbilds", se obtém uma imagem de

(32) Cf. K. Marx e F. Engels, Manifest der komunistischen Partei, MEW, t. 4, Berlin, 1972, pp. 463 e 466.

(33) Cf. Raúl Fornet-Betancourt, Transformación intercultural de la filosofia, pp. 338-341. 
mundo calculável, programável, marcada pelo determinismo e pela necessidade cega da mercantilização do universo em todos os seus aspectos, tanto reais como virtuais.

Como é natural, esta configuração metafísica do mundo arrasta consigo uma "revolução antropológica" que se traduz na conformação do ser humano e da sua subjectividade ao espírito de sistema subjacente a esta visão do mundo, em que a sua consciência como sujeito se vê sobredeterminada pela sua consciência de "proprietário", "dominador" e consumidor, com uma consequente redução das relações "sociais" a meras "relações mercantis", o que significa uma profunda transformação do homem no mais íntimo do seu ser e da sua essência ${ }^{(34)}$. Como, no entanto, toda a orientação para o consumo é marcada por um processo exterior, que assenta na criação artificial de necessidades que são estandardizadas por padrões exteriores às realidades regionais e a dinâmicas culturais específicas, a transformação dos critérios de orientação implica obviamente transformações praxísticas que se repercutem nos projectos societais que inconscientemente são introjectados em todo este processo. Fornet-Betancourt sintetiza magistralmente todas estas transformações nas seguintes palavras: "Com a 'revolução antropológica' que leva consigo a imposição do 'espírito' do neoliberalismo, assistimos, no fundo, à emergência de uma 'subjectividade' humana em estado hipnótico. Para resumir a nossa crítica também poderíamos falar de 'subjectividade' cuja memória da humanitas foi neutralizada pelo fascínio das imagens do sistema" ${ }^{\prime \prime 35}$. Ligada, finalmente, a esta perspectiva metafísica e antropológica há também uma determinada filosofia da história e uma determinada visão do progresso: trata-se de conceber a marcha do mundo a partir da tendência para a globalização dos mercados e do capital: essa parece ser a grande utopia do neoliberalismo, fixando como horizonte não só a unificação mas sobretudo a totalização de todos os sistemas económico-financeiros a nível mundial sob o mito da aldeia global. A sua construção baseia-se, afinal, numa homogeneização das necessidades e do consumo cujos padrões entram na casa de todos os cidadãos não só pelos televisores e pelas revistas, mas, actualmente, através da ciberpublicidade e do cibercomércio, que não é uma projecção a nível mundial da cultura de

(34) Cf. idem, ibidem, pp. 342-344.

(35) Idem, ibidem, p. 345. 
cada uma das regiões do mundo, mas da cultura comercial das regiões do centro e do chamado primeiro mundo que, desse modo, se sobrepõe a todos os outros mundos segundos ou periféricos. Mas o que esta filosofia da história comporta de mais grave é ainda e duma forma determinante e paralisante a crença na falta de alternativas de que se faz acompanhar, como se este movimento fosse o único movimento possível à escala mundial ${ }^{(36)}$.

As consequências de todo este processo, quando perspectivadas ao nível da filosofia da cultura e numa intersecção com a problemática da mestiçagem transformam aquilo que, pela sua ligação à universalização (que deveria supor uma unidade na diversidade), implicaria o respeito pela diferença e pela alteridade e o desenvolvimento de uma ética da solidariedade, num fenómeno de que decorrem afinal os efeitos contrários de que enunciaríamos os seguintes: a mútua implicação entre inclusão violenta e exclusão social como marca específica da globalização neoliberal na forma como dá continuidade à colonização desenvolvida entre o século XV e o século XX; a eliminação do território das culturas e dos contextos materiais para o seu desenvolvimento e para a sua afirmação; a homogeneização cultural resultante dessa eliminação e da exclusão que lhe é correlativa, reduzindo o potencial fecundador da mestiçagem implicada no processo da globalização a um efeito de superfície sem qualquer correspondência nos núcleos interiores identificadores de cada cultura no seu carácter mestiço e na riqueza plural da sua memória histórica.

A dialéctica entre inclusão violenta e exclusão social deriva da assimetria que caracteriza o acesso das diversas culturas ao World-system da globalização, que pela sua própria natureza acaba por marginalizar as vítimas dos sistemas integradores que dispõem das competências e sobretudo da força que lhes permite trańsformar o global no seu mundo (ou, analogamente, o seu mundo no mundo global). Se nos primeiros momentos a violência com que se dá essa inclusão e com que se opera essa exclusão é uma violência explícita, no último momento, aquele que caracteriza propriamente a globalização, ela é sobretudo uma violência simbólica (muitas vezes suportada pela exploração económica), mas não menos irracional, permitindo àqueles que se opõem às leituras optimistas da globalização neoliberal criticar também a forma como se procura

(36) Sobre esta filosofia da história, cf. idem, ibidem, pp. 304-406. 
aplicar a Ética do Discurso a estes processos que, pressupondo uma simetria nos participantes de uma comunidade argumentativa ideal, se vê aqui confrontada com uma profunda assimetria que faz com que os mais pobres, os discriminados socialmente, os sem-terra e sem voz sejam excluídos de todo este processo ${ }^{(37)}$, num movimento em que o seu chão natural se vê ecologicamente destruído pela voracidade predadora do centro, e, simultaneamente, a maioria da humanidade se vê estruturalmente empobrecida numa espiral que parece não ter fim. Deste modo, aquilo que parece uma mestiçagem promovida pela globalização mais não é do que a escrita na pele dos mais pobres e dos mais fracos da dominação colorida, às vezes com as tintas da Benetton, das culturas dominantes.

A globalização elimina também e simultaneamente as condições de possibilidade de uma autêntica mestiçagem, na medida em que priva as culturas do seu território, ou seja, da estrutura material indispensável para o seu desenvolvimento ${ }^{(38)}$. Cada cultura forma, com as ideias, as artes e os costumes que são os seus, um mundo em sentido pleno do termo, ou seja, tem um mundo que lhe é próprio. Ora o que se verifica, na prática, é um conflito entre o contexto da globalização (económico, financeiro, político, informático e inclusivamente militar) e os contextos oprimidos das culturas da humanidade. Retomando a concepção ecológica de cultura a que anteriormente fizemos referência, é indispensável contrariar a voragem ecossistémica da globalização que destrói os ecossistemas particulares de cada cultura através de uma violência irracional e, muitas vezes, invisível.

De tudo isto resulta então, em terceiro lugar, que a globalização neoliberal, mais do que promover uma mestiçagem séria, promove uma homogeneização cultural, precisamente porque a globalização é uma

(37) Cf. E. Dussel, art. cit., pp. 125-130. Também Miguel Baptista Pereira, ("Alteridade, linguagem e globalização", p. 27) assume idêntica posição crítica à Ética do Consenso de Habermas: "O fim do discurso de Habermas é o consenso em que domina uma opinião única, cujo sujeito é um 'super-nós' totalmente esclarecido. Ora, isto destrói a multiplicidade de opiniões, histórias, línguas, costumes, etc., que enriqueceram a nossa vida pequena e curta, e impõe-se como proibição autoritária do discurso e poder unificador da razão única contra a dispersão das narrações míticas".

(38) Cf. Raúl Fornet-Betancourt, Transformación intercultural de la Filosofia, pp. 178-181 e 283-284. 
universalização que parte de cima e se impõe de cima para baixo e não uma universalização que, tendo como sujeito o singular concreto, se desenvolve de baixo para cima enriquecendo os patamares superiores a que em cada movimento se eleva. Também Paul Ricoeur, na sua crítica à universalização científico-técnica, antecipara claramente a homogeneização que parecia resultar de todo este processo, afirmando: "enfim, pode dizer-se que se desenvolve através do mundo um género de vida igualmente universal; este género de vida manifesta-se pela uniformização inelutável da habitação, do vestuário (é o mesmo fato que corre o mundo)", considerando que estes géneros de vida derivam da sua racionalização pela técnica em processo de universalização, sendo essas técnicas que estão na base de "uma cultura de consumo de carácter mundial que desenvolve um género de vida de carácter universal"(39). Aliás, o paradoxo dos países em vias de desenvolvimento centra-se, segundo este autor, precisamente aí, pois o mesmo processo que permite a esses países acederem à civilização técnica universal, "constitui uma espécie de subtil destruição não apenas das culturas tradicionais [...] mas do núcleo criador das grandes civilizações, das grandes culturas, este núcleo a partir do qual interpretamos a vida e que chamo, por antecipação, o núcleo ético e mítico de toda a humanidade"(40). Destruindo as culturas na sua singularidade e destruindo simultaneamente a possibilidade da sua sobrevivência, a globalização transforma-se, como refere Srinivasa Rao, numa "ideologia que está unida às noções de cultura monolítica e de dependência", tendendo a ideia de aldeia global, no contexto da globalização, para uma situação "em que se não distingue a inter-relação da dependência"(41). Entretanto, alguns espíritos mais optimistas crêem que é de facto um espírito universal que se encontra aqui em estado emergente, havendo até quem identifique a telépolis resultante da World Wide Web com a realização prática da noosfera visionada por Theillard Chardin na sua descrição do processo de

(39) Paul Ricoeur, "Civilisation universelle et cultures nationales", p. 289.

(40) Cf. idem, ibidem, p. 292.

(41) Srinivasa Rao, "Las perspectivas filosóficas de la asimetría cultural y los retos de la globalización", in Raúl Fornet-Betancourt (Ed.), Culturas y Poder, p. 56. 
hominização ${ }^{(42)}$. Outros, menos optimistas, verão no culto da internet uma ameaça para os vínculos sociais ${ }^{(43)}$, sublinhando, entre os efeitos perversos deste novo culto, um recuo das liberdades ${ }^{(44)}$, a dessincronização das actividades sociais ${ }^{(45)} \mathrm{e}$ um crescimento das desigualdades ${ }^{(46)}$. Trata-se, mais uma vez, de saber se a diferença nas oportunidades de acesso às novas técnicas de comunicação que constituem o instrumento desta "globalização virtual" não são equivalentes ao domínio das armas

(42) Pierre Lévy, por exemplo, na sua obra World Philosophie (Paris, Éditions Odile Jacob, 2000), que abre com uma citação de Theillard Chardin, desenvolve, através de um longo capítulo, esta ascensão à noosfera ("La montée vers la noosphère, pp. 143-180), no qual afirma explicitamente (p. 168): “Or, le processus d'hominisation n'est pas terminé. Avec le feu, l'art et l'écriture notre espèce n'a pas encore fini de dresser la liste des grands objets anthropologiques qui définissent l'humain irréversiblement. Nous avons encore à grandir. Une nouvelle étape à franchir se présente devant nous. Nous venons de produire un objet anthropologique qui est à la fois une technique, un langage et une religion". Esse objecto é o computador que quase se transforma em motivo de um hino de louvor (pp. 169-170): "L'ordinateur ou le cyberespace fait passer la conscience humaine à un niveau supérieur, $c^{\prime}$ est-à-dire, qu'il lui permet de prendre contact avec elle même et de s'unifier - ici et maintenant - à l'échelle de l'espèce. [...] Libérés de la raison et du calcul par l'ordinateur nous sommes en train de rassembler notre intelligence collective. Jusqu'à ce que nous découvrions ensemble ce qu'il y a de plus universel, de plus éternel et de plus concret, l'instant présent, et la lumière qui brille et brûle en lui perpétuellement, le feu unique de la conscience".

(43) Cf. Philippe Breton, Le culte de l'internet. Une menace pour le lien social?, Paris, La Découverte, 2000.

(44) Idem, ibidem, p. 115: "Nos sociétés libérales démocratiques on un gant de velours pour ce qui concerne le respect des droits individuels formels. L'Internet systématique serait en revanche un redoutable outil entre les mains de fer d'un régime non démocratique".

(45) Idem, ibidem, p. 117: "Dans ce monde moyen, sans surprise et sans conflit, les interactions virtuelles se déroulent dans un espace où les uns sont toujours décalés par rapport aux autres".

(46) Depois de sublinhar que toda a África no seu conjunto dispõe de menos linhas telefónicas que Nova Iorque ou que Tóquio, Philippe Breton, numa crítica explícita a Pierre Lévy, acrescenta (p. 118): "Nous sommes très loin des discours sur la 'réunification de la conscience universelle' et plus proche de la figure, hélas classique, de l'accroissement de la domination de quelques-uns, du fait de la maîtrise des outils qui donnent la puissance". 
de fogo pelos portugueses e pelos espanhóis nos séculos XV e XVI e que levaram a transformar as formas prévias de globalização que foram as descobertas num autêntico massacre de povos e culturas.

Estas três consequências, geração de excluídos, eliminação dos territórios das culturas singulares e homogeneização, permitem-nos compreender o sentido e o alcance da crítica de Miguel Baptista Pereira a esta globalização a que ele chama "predadora": "Tornou-se necessário instaurar um processo à globalização, no sentido em que é predadora, apontando com o dedo acusador o seu impacto sobre vários aspectos da vida: aumento da pobreza e da exclusão, desmantelamento das economias locais, homogeneização da cultura, ameaças sobre o meio-natural, a saúde, a bio-diversidade, os processos democráticos, a que se deve acrescentar o neocolonialismo veiculado pelo poder técnico-económico das organizações transnacionais"(47).

\section{Problematização do conceito de mestiçagem}

As considerações em torno das implicações culturais da globalização permitiram-nos ir percebendo progressivamente que também ela produz um fenómeno de cruzamento de culturas mas em que a alteridade e a diferença não são suficientemente salvaguardadas, resultando, por isso numa mestiçagem em que há, à partida, pólos dominantes que sobredeterminam as cores de que ela se reveste nas suas manifestações concretas. Há, assim, um multiculturalismo e uma mestiçagem adequados à aldeia global que estão muito mais próximos do colonialismo ou do folclore que o disfarçava do que de uma assunção da natureza dialógica, dinâmica e plural da cultura e da nossa situação de pertença relativamente a ela. Por esse motivo, é necessário de facto interrogarmo-nos sobre o que pretendemos dizer e o que queremos efectivamente significar quando caracterizamos um conjunto de fenómenos da sociedade contemporânea com a designação de mestiçagem. Trata-se, por outras palavras, de captar as dinâmicas que este conceito encobre e potencializar as que nos parecem positivas no projecto societal que com ele pretendemos abrir.

(47) M. B. Pereira, art. cit., p. 36. 
Como refere Gruzinski, chamando a atenção para as ambiguidades da nossa linguagem, "juntar, misturar, urdir, cruzar, encaixar, sobrepor, justapor, interpor, imbricar, colar, fundir, etc., são palavras que se aplicam à mestiçagem e cobrem, com uma profusão de vocábulos, a imprecisão das descrições e o carácter vago do pensamento"(48). Se consultarmos o Dicionário da Academia das Ciências, encontraremos, ente outras, as seguintes definições de mestiçagem: "cruzamento de pessoas de raças e culturas diferentes" ou, por analogia, "acção de cruzar ou misturar elementos de diferentes origens", considerando-se mestiço, em sentido primeiro e original, aquele "que é filho de pais de grupos genéticos diferentes"(49). Vemos, pois, que a ambiguidade que inicialmente percebemos neste conceito tão pouco nos é esclarecida com a sua inspecção semântica. Tal inspecção poderá, aliás, introduzir dados que ainda complexificam mais a análise do fenómeno, na medida em que mestiço se contrapõe, habitualmente, a puro, posição que, no momento em que se deixa envolver por uma perspectiva axiológica de orientação maniqueísta, privilegiará, ainda que inconscientemente, o puro como o bom e o mestiço como o contaminado, introduzindo assim distorções que, estereotipadamente, se insinuam de uma forma pré-reflexiva e pré-crítica na apreciação deste fenómeno. Entretanto, se a aproximação entre mestiçagem e globalização não nos proporciona muitos esclarecimentos sobre a ambiguidade deste conceito, se a análise semântica nos deixa em situação idêntica, o seu cruzamento com o conceito de multiculturalismo também não nos deixa em melhor posição. Efectivamente, a mesma ambiguidade ou pluralidade de sentidos que atinge a mestiçagem, atinge também o multiculturalismo. É que o multiculturalismo começa por ser um facto que se traduz na coexistência de várias culturas numa proximidade física e humana, mas facilmente evolui para um projecto de sociedade, que o conceito americano de melting-pot tão bem exprime com toda a sua fragilidade, dado que, ao postular, ainda que inconscientemente, um primado do grupo a que se pertence, uma espacialização das diferenças, uma jurisdição específica e complexa que garante os direitos de cada um, um reconhecimento do relativismo cultural e a expressão das diferenças no espaço

(48) S. Gruzinski, ob. cit., p. 36.

(49) Academia das Ciências de Lisboa, Dicionário da Língua Portuguesa Contemporânea, II vol., Lisboa, Editorial Verbo, 2001, p. 2450. 
público ${ }^{(50)}$, pode dar origem a formas de vivência da diferença e da pluralidade que não ultrapassam a cultura de mosaico com que se pretendeu definir a cultura pós-moderna na sua fragmentação. Daí que não poucos autores se tenham manifestado abertamente contra o projecto do multiculturalismo ${ }^{(51)}$, por, segundo eles, contribuir para um enfraquecimento ou para uma dissolução dos vínculos sociais e para uma concepção meramente atomista da vida colectiva. Por isso, quando se põe a questão da mestiçagem numa sociedade multiétnica ou multicultural, o problema reside em saber se tal mestiçagem constitui ou não uma forma de superação da mera coexistência, sobreposição ou justaposição de culturas diferentes.

Neste contexto e em ordem a uma clarificação dos sentidos positivos de mestiçagem, vale a pena distinguir entre mestiçagem de superfície e mestiçagem em profundidade. Porque, quando falamos de cultura, ela tem também a sua pele, de que o design e a moda seriam uma das metáforas $^{(52)}$, tal como tem o corpo que tal pele reveste. A que nível se opera a mistura que se afirma na mestiçagem? Ao nível das meras representações exteriores? Serão as ruas de Atenas ou de Tóquio, com as designações escritas nos seus próprios caracteres, mas com os placards publicitários a fazer a promoção, em língua inglesa, de marcas americanas, símbolo de alguma mestiçagem? Será um zapping de um holandês, numa casa de Trás-os-Montes, pelos múltiplos canais da TV por cabo ou por satélite, um exemplo de mestiçagem? E a pele dos nossos filhos onde caligraficamente se inscrevem tatuagens com símbolos chineses, será também ela exemplo de mestiçagem? Qual a diferença entre essa pele e "um tupi tangendo um alaúde" de que nos fala Mário de Andrade? O fenómeno da mestiçagem, para significar algo mais do que um mero

(50) Cf. M. Abdallah-Pretceille, ob. cit., pp. 26-28.

(51) Veja-se, por exemplo, o livro de Giovanni Sartori, La sociedad multiétnica. Pluralismo, multiculturalismo y extranjeros, trad. de M. A. Ruiz de Azúa, Madrid, Taurus, 2001, que é todo ele uma crítica desferida contra os partidários do multiculturalismo, a começar pelo próprio $\mathrm{Ch}$. Taylor e a acabar nos seus representantes europeus.

(52) Cf. Derrick de Kerckhove, A pele da cultura. Uma investigação sobre a nova realidade electrónica, Lisboa, Relógio d'Água, 1997, p. 212: "Sendo a forma exterior visível, audível ou texturada dos artefactos culturais, o design emerge como aquilo a que poderíamos chamar a pele da cultura". 
sincretismo de tendências religiosas, culturais ou étnicas, tem de ser pensado, por um lado, a partir daquilo que o constitui, que é a fronteira na sua dupla dimensão de marca e de ponte de ligação, ou seja, tem de ser pensado pensando o intermédio, o espaço de mediação que a mestiçagem preenche e em que se realiza ${ }^{(53)}$. Pela categoria de fronteira nessa dupla acepção, a mestiçagem remete para algo mais que a justaposição ou a mera fusão: remete para a tensão constitutiva da relação de diferentes, para o dinamismo que ela implica (a mestiçagem está sempre in fieri), e para a conflitualidade criadora em que projectivamente opera. Por esse motivo, ela tem de ser pensada também, por outro lado, descendo à profundidade em que a pele se faz corpo com o corpo da cultura, em que a seiva do discurso se mistura com a seiva do pensamento e se faz carne no corpo do homem, pois, como diz Ricoeur, "aos sincretismos é necessário opor a comunicação, isto é, uma relação dramática na qual eu me afirmo, de cada vez, na minha origem e me entrego à imaginação do outro segundo a sua outra civilização"(54). Significa isto que a mestiçagem, em sentido profundo e mais autêntico, não pode terminar na metáfora, nesse "falar para lá de" que é, na sua própria definição, um falar trans-referencial, mas deve passar da metáfora à metanóia, realizando assim um mergulho em profundidade, já que metanóia é transformação, mas transformação a partir de dentro, a partir do nous, ou seja, do núcleo intelectual que dá sentido ao mundo e à acção, à acção no mundo e ao mundo da aç̧ão. É esta metanóia que está de algum modo pré-contida na noção de "fusão de horizontes" que Ch. Taylor, inspirando-se em Gadamer ${ }^{(55)}$, considera como condição indispensável para um equilibrado encontro com o outro pela transformação dos critérios em que se apoiam os nossos juízos de valor ${ }^{(56)}$.

Este projecto (já que se trata mais de um projecto do que de um facto) de uma mestiçagem em profundidade articula-se por sua vez com o conceito de identidade dinâmica e plural a que atrás fizemos referência: se a mestiçagem é uma forma de identidade, a identidade que ela postula

(53) Cf. S. Gruzinski, ob. cit., pp. 42-45.

(54) P. Ricoeur, "Civilisation universelle et cultures nationales", p. 300.

(55) Cf. H.-G. Gadamer, Gesammelte Werke, Wahrheit und Methode, I, Grundzüge einer philosophischen Hermenutik, Tübingen, Mohr, 1986, pp. 311-312, 380 e 401.

(56) Cf. Taylor, "A política do reconhecimento", ed. cit., p. 88. 
afirma-se através de estratégias de negociação e de procedimentos dialógicos no confronto dialéctico com o outro e com os outros. A relação e a interaç̧ão são coessenciais e codeterminantes da identidade que aqui se postula ${ }^{(57)}$, pois é através delas que se constitui o sentido do sujeito, seja ele o indivíduo ou o grupo, na doação de sentido entre o eu e o tu e entre o tu e o eu, dado que é nesse mútuo e recíproco investimento que nos percebemos na nossa identidade-em-mundo, naturalmente diferente da nossa identidade solipsista. Este fazer-se da nossa identidade é simultaneamente uma apropriação, já que o ser humano não se limita a ser determinado pelo que o envolve mas determina-o também ele próprio e, por isso, a sua identidade não é apenas um efeito da cultura que assimila, mas emerge dialecticamente no processo de criação e de produção livre dessa cultura, de abertura e de desenvolvimento do seu potencial crítico e transformador ${ }^{(58)}$.

A identidade que assim se gera implica uma gestão das relações de aproximação e de recusa do outro, que, muitas vezes, passa por relações de poder e afirmação de domínio, o que nos obriga a perguntar por que razão em certas sociedades e em determinados contextos se geram "traços de identidade que excluem outros traços de identidade, por que razão eventualmente certas práticas monopolizam a pertença simbólica ao grupo" (59). Trata-se, no fundo, de ganhar consciência de que, se, muitas vezes, "toda a identidade é mais contra alguém do que a favor de alguém", há dinâmicas em que se geram identidades dominantes e que expulsam e relegam outras identidades alternativas" ${ }^{\prime \prime(60)}$, o que faz com que a história da identidade ou das identidades de um grupo seja também a história dos seus conflitos. Mas se articularmos esta história dos conflitos em que se gera a identidade de um grupo com a problemática da mestiçagem, outro tópico passa para primeiro plano, merecendo a nossa atenção e que se prende com a pluralidade de mestiçagens, pluralidade essa que tem a ver não só com o facto de que, em termos

(57) Cf. M. Abdallah-Pretceille, ob. cit., p. 55.

(58) Cf. Raúl Fornet-Betancourt, Transformación intercultural de la filosofía, ed. cit., pp. 377-379.

(59) Emilio Lamo de Espinosa, "Fronteras culturales", in Emilio Lamo de Espinosa, (Ed.), Culturas, estados ciudadanos. Una aproximación al multiculturalismo en Europa, Madrid, Alianza Editorial, 1995, p. 29.

${ }^{(60)}$ Idem, ibidem. 
finais, cada mestiço é singular e único, mas também com a pluralidade de processos, relativamente aos quais não podemos ser axiologicamente neutrais, em que se gera a ou as mestiçagens: é que há mestiçagens activas e mestiçagens passivas, mestiçagens queridas e mestiçagens impostas, mestiçagens que resultam de um acto de amor e mestiçagens que resultam de um acto de violação. A conjugação da mestiçagem com a interacção e o conflito obriga-nos, pois, a perceber também a pluralidade de sentidos de que se reveste a mestiçagem.

Esta pluralidade de sentidos pode ser especialmente operacionalizada e potencializada quando se cruza a mestiçagem com a globalização, com a consciência histórica de que a globalização que vivemos ou que sofremos hoje não é senão o eco actualizado de uma outra globalização que gerou uma forma de mestiçagem imposta pela força do poder e pela força das armas: a globalização do século XV e dos séculos que se lhe seguiram e em que a exportação da mão de obra escrava da África para a América fez com que a miscigenação fosse sobretudo uma violentação de povos e culturas conseguida com base no chicote, na pólvora, nas correntes de ferro e no sémen derramado em corpos banhados de sangue e suor. Verifica-se isso, naturalmente, na mestiçagem biológica, que é o chão natural da própria mestiçagem, mas verifica-se também na mestiçagem cultural, que é aquela que agora nos interessa interrogar. E quando se fala de mestiçagem cultural neste contexto e neste cruzamento de séculos é ainda e sempre o jogo entre a civilização e a barbárie que está em causa e as formas que ele assume. Poderiam supor os primeiros colonizadores que a expansão da "sua" civilização era uma forma de superação da barbárie dos povos selvagens ou primitivos. Mas a história, que é sempre o juiz supremo dos grandes processos civilizacionais, veio mostrar-nos como, afinal, são muito relativos estes conceitos e que toda a civilização, para além de essencializar em categoria natural aquilo que é uma mera construção social classificadora do outro e do diferente (como acontece com a categoria de bárbaro na sua contraposição à categoria de civilizado) gera, a partir daí, a sua própria barbárie sob a pia capa de estender os princípios de uma suposta civilização universal. A ocupação da África e da América ao longo de séculos mostra como, de facto, em nome da civilização se cometeram as maiores barbaridades. Mas, para além disso, cedemos facilmente à tentação de historicizar a relação civilização/ /barbárie, como se o nosso tempo fosse um tempo correspondente à superação de formas históricas menos civilizadas. Todavia, nem sempre 
é fácil operar de uma forma tão linear com as nossas reconstruções sociais do tempo e da história. Com efeito, o nosso tempo é também ele produtor e reprodutor de civilização e barbárie numa dialecticidade interna, sendo a barbárie que geramos a outra cara do nosso processo civilizacional, e, por isso, poderíamos dizer, com Fornet-Betancourt, que também nós "temos hoje a nossa própria 'Barbárie'; uma 'Barbárie' pós-civilizatória que se patentiza na destruição das culturas, na exclusão social, na destruição ecológica, no racismo, no reducionismo da nossa visão da criação, no desequilibrio cósmico que gera o modelo de vida propagado pelos nossos meios de publicidade, na fome e desnutrição"(61). A mestiçagem de que hoje falamos é também tudo isto e, por isso, não podemos ser demasiado lineares na sua apreciação, devendo lançar um olhar atento e crítico sobre os processos através dos quais se realiza essa mestiçagem. Não haverá, de facto, muita barbárie misturada com a mestiçagem cultural? Não estará o furacão da globalização a produzir também ele uma mestiçagem de terra queimada através da sua força destruidora que elimina as diferenças culturais e destrói as identidades plurais que o tempo, no seu lento destilar de novas formas de vida e de pensamento, tem vindo a sedimentar numa outra forma de mestiçagem, ao longo da história pacífica dos homens e do diálogo festivo das suas expressões culturais e artísticas? É que hoje, como ontem, a mestiçagem cultural pode ser conseguida à custa da invasão e, quando as culturas são invadidas, perdem os seus contextos materiais e os seus ecossistemas de desenvolvimento, acabando as suas paisagens por ser desfiguradas pela presença dominante, ainda que com um certo aspecto mestiço, das espécies invasoras.

\section{A mestiçagem em profundidade e o diálogo intercultural}

Quando se passa de uma mestiçagem de superfície para uma mestiçagem em profundidade e de uma mestiçagem imposta para uma mestiçagem sentida, querida e assumida, opera-se um cruzamento fecundo entre mestiçagem e interculturalidade que postula o diálogo entre culturas como a sua forma de realização e que se afirma como

(61) Raúl Fornet-Betancourt, Transformación intercultural de la Filosofía, p. 195. 
alternativa consistente à mestiçagem subjacente à globalização neoliberal. Mas como esse diálogo se desenha numa situação de assimetria, no que se refere aos planos económico, político e científico-técnico, para já não falar do plano militar, a tese que proponho é a de que a configuração deste diálogo intercultural, hoje e mesmo nas sociedades ocidentais, onde ainda há países e culturas do centro e países e culturas da periferia, muito poderá receber de uma leitura atenta dos contributos que têm vindo a ser proporcionados por alguns dos autores que desenvolveram a sua reflexão no contexto de "culturas invadidas" desde a primeira globalização e que, por isso, esboçaram, num clima de cultura silenciosa, princípios e instrumentos conceptuais que constituem uma resposta adequada ao sentimento de rapina com que a cultura de consumo das grandes multinacionais nos pretende mestiçar (sendo conveniente ter em conta que essa cultura de consumo das grandes multinacionais não se manifesta apenas ao nível dos artefactos técnicos, da alimentação e do vestuário, mas invade esferas mais profundas da actividade cultural e artística, como a música e o cinema, por exemplo). Neste contexto, as correntes filosóficas hoje conhecidas como a Filosofia e a Ética da Libertação, que encontram em Enrique Dussel um dos seus principais expoentes, têm vindo a desenvolver um conjunto de reflexões extremamente interessantes e pertinentes para a redefinição do que hoje se vai também já chamando uma "filosofia intercultural" ou, na expressão de Fornet-Betancourt, uma "transformação intercultural da Filosofia" e de que gostaria agora de retirar algumas direcções de reflexão, de pesquisa e de orientação prática.

Importa, em primeiro lugar, referir alguns pressupostos em que poderá assentar esta Ética da Libertação ao serviço de um diálogo entre culturas e de uma sã mestiçagem cultural. Ao fazê-lo não irei, naturalmente, recuperar pressupostos antropológicos já desenvolvidos em outros textos (como a concepção dinâmica da natureza humana, o carácter inalienável da liberdade cu a tolerância como dever de reciprocidade face ao direito à igualdade $\left.{ }^{(62)}\right)$, mas centrar-me-ei em três outros pressupostos que, neste contexto, me parecem mais pertinentes: a desobediência cultural, o princípio libertação e a competência pluricultural.

(62) Cf. João Maria André, "Pluralidade de crenças e diferença de culturas. Dos fundamentos filosóficos do ecumenismo de Nicolau de Cusa aos princípios actuais de uma educação intercultural", pp. 490-497. 
A desobediência cultural ${ }^{(63)}$ corresponde à legitimidade com que uma cultura invadida pode desobedecer aos imperativos da cultura colonizadora na sua vocação para a fragilização e consequente domínio das outras culturas, mas proporciona simultaneamente a capacidade de uma cultura de origem se cruzar fecundamente com outra cultura. Neste contexto, a desobediência cultural desenvolve mecanismos que são simultaneamente de resistência e de transformação: de resistência à cultura que se impõe pela força e de transformação pela crítica às figuras estabilizadas da própria cultura, de tal maneira que o futuro é um espaço aberto que deve ser permanentemente refundado a partir de novas interacções, não tendo nenhuma cultura o direito a reduzir o mundo à visão que dele tem. Partir para o diálogo intercultural tendo como pressuposto a desobediência cultural é também e ao mesmo tempo fazer da cultura uma permanente opção e assumir por isso a liberdade como forma de habitar o espaço cultural ${ }^{(64)}$, o que implica, simultaneamente, assumir o diálogo como conflito de tradições que se escrevem no presente e na memória da(s) nossa(s) cultura(s) e assumir simultaneamente esse conflito como diálogo, num permanente processo de dessacralização da herança cultural que nos é legada. Mas é também certo que assumida a desobediência cultural no contexto de uma globalização de rapina ela significa, antes de mais, uma opção ética libertadora dos sistemas de exclusão mais ou menos inerentes ao processo de afirmação de qualquer cultura, tomando o partido dos oprimidos e dos "sem abrigo cultural", que o são por terem sido despojados da casa cultural em que moravam.

É assim que ganha sentido o segundo pressuposto que a Filosofia Latino-Americana, nos seus desenvolvimentos a partir dos anos setenta do século XX, nos proporciona: o princípio-libertação. Tal princípio surge no contexto da afirmação de uma Ética da Libertação( ${ }^{(65)}$, desenvolvida a

(63) Retomo o conceito, de uma forma crítica e um pouco mais abrangente, de Raúl Fornet-Betancourt, Transformación intercultural de la Filosofía, pp. 183-189.

(64) Diz a este propósito Raúl Fornet-Betancourt (ibidem, p. 187): "Así el sujeto humano nace culturalmente situado; pero esta situatividad no es un destino; porque, por los procesos de apropriación indicados, cada sujeto humano puede resituar su situatividad cultural".

(65) Para uma compreensão mais exaustiva do que é a Ética da Libertação, cf. E. Dussel, Ética de la liberación en la edad de la globalizacón y de la exclusión, Madrid, Editorial Trotta, 2002. 
par da Teologia da Libertação, mas numa sede e com uma discursividade filosóficas e numa significativa simultaneidade com outros movimentos idênticos, igualmente críticos, no quadro da periferia pós-colonial, nomeadamente na Índia e na África, que tiveram a sua expressão teórica nos chamados "subaltern studies". Encontrando as suas referências em autores como Marx (num marxismo renovado), Foucault, Levinas, a Escola de Frankfurt e ainda Franz Fanon, com a sua obra Os condenados da Terra, e partindo do contributo de diversas vertentes críticas da razão moderna e do sujeito cartesiano, a Filosofia da Libertação desenvolve uma filosofia política crítica situada e localizada nos sistemas de opressão em que vive grande parte dos países da América Latina e no processo histórico de colonização a que foram sujeitos. A desconstrução da Modernidade, feita numa articulação entre a teoria e a prática, permite-lhes dar conta da ligação intrínseca entre "je pense, je suis" de Descartes e o "yo conquisto" de Hernán Cortés no México no século XVI, ao mesmo tempo que lhes permite também ver nos "excluídos e vigiados" nas "reduções", aldeias e doutrinas da América Latina uma antecipação dos manicómios e das prisões panópticas de Foucault ${ }^{(66)}$. No entanto, esta localização do pensamento com o seu potencial libertador leva os mesmos autores a assumir uma posição relativamente crítica face às suas fontes do Velho Continente, ainda marcadas por uma perspectiva demasiado europeia, porque agora o Outro passa a ser também o oprimido por uma nova ordem económico-política internacional, que gera continuamente novas vítimas e, por isso, "o filósofo crítico latino-americano, como o concebe a Filosofia da Libertação, atribui-se a responsabilidade de lutar pelo Outro, a vítima, a mulher oprimida do patriarcalismo, as gerações futuras às quais vamos deixar uma terra destruída, etc. (todos os tipos de alteridade possível) a partir da sua consciência ética situada"(67). Esta perspectiva permite a enunciação de um princípio material universal da ética nestes termos: "aquele que actua eticamente deve (como obrigação ou dever-ser ético) reproduzir e desenvolver auto-responsavelmente a vida de cada sujeito humano, tendo como regra enunciados normativos com pretensão de verdade prática, numa comunidade de vida, a partir de

(66) Cf. E. Dussel, Hacia una filosofía política crítica, Bilbao, Editorial Desclée de Brouwer, 2001, pp. 441-446.

(67) Idem, ibidem, p. 445. 
uma 'vida boa' cultural e histórica [...] que se partilha solidariamente tendo por referência última toda a humanidade e, por isso, com pretensão de universalidade" ${ }^{\prime(68)}$. Face às vítimas, tal princípio implica, em primeiro lugar, e no seu momento negativo, a crítica da não-verdade das condições que originam a vítima, e, no seu momento positivo, o empenhamento em criar consolidariamente meios para transformar essas condições e, consequentemente, o empenhamento na transformação do sistema-mundo que, no seu processo de exclusão, gera as vítimas da globalização( ${ }^{(69)}$. O que se activa, a partir deste processo, é uma praxis de libertação que, aplicada ao diálogo intercultural, obriga a um repensamento das culturas tendo em conta a memória da libertação das vítimas, com base numa reflexividade e numa comunicação intersubjectiva que se apropria das virtualidades da Ética do Discurso e que elege a solidariedade como modo de ser ${ }^{(70)}$, numa reformulação da célebre máxima de Ortega, no sentido de que o sujeito é "ele e o outro"; e de que "se não salva o outro, não se salva a ele"(71).

Um terceiro pressuposto para podermos avançar numa compreensão mais libertadora do diálogo intercultural reside no reconhecimento de que cada ser humano é capaz de, simultaneamente, desenvolver competências em várias culturas, ou seja, em "múltiplos sistemas de esquemas de percepção, pensamento e aç̧ão" (72). Se algum efeito positivo tem a globalização em termos culturais é dar-nos alguns instrumentos para o desenvolvimento dessas múltiplas competências, de tal maneira que os membros de um determinado grupo étnico, por exemplo, apesar de partilharem um conjunto de sistemas de referência cultural entre si, inserem-se simultaneamente em outros grupos, estruturados a partir do trabalho, da religião ou do ócio, partilhando também de outros sistemas de referência. Ou seja, se a identidade de um indivíduo é plural,

(68) E. Dussel, "La globalización y las víctimas de la exclusión", p. 131.

(69) Cf. idem, ibidem, p. 133.

(70) Cf. Raúl Fornet-Betancourt, Transformación intercultural de la filosofía, pp. 200-203.

(71) Idem, ibidem, p. 203, em que o autor remete para a frase original de José Ortega Y Gasset, em Meditaciones del Quijote, Obras Completas, I, Madrid, 1983, p. 322: "Yo soy yo y mi circunstancia, y si no la salvo a ella no me salvo a yo".

(72) Cf. F. Javier García Castaño, Rafael A. Pulido Moyano e Ángel Montes del Castillo, "La educación multicultural y el concepto de cultura", p. 73. 
também as suas competências culturais são plurais, possibilitando-lhe uma resposta no contexto da sua identidade múltipla e dinâmica. Este pressuposto não deixa de implicar um certo questionamento da noção de incomensurabilidade, desenvolvida por Thomas Kuhn ${ }^{(73)}$ e por Feyerabend ${ }^{(74)}$ nas suas explicações do processo paradigmático de desenvolvimento do conhecimento científico, quando transposta para o plano cultural, obrigando-nos a perguntar se, de facto, será absolutamente impossível traduzir núcleos de um universo cultural na linguagem de outro universo cultural. Colocando a pergunta, Paul Ricoeur é optimista ao afirmar: "Sim, creio que é possível compreender por simpatia e por imaginação o outro de mim [l'autre que moi], como compreendo uma personagem de um romance, de teatro, ou um amigo real mas diferente de mim; mais, posso compreender sem repetir, representar-me sem reviver, fazer-me outro ficando eu próprio. Ser homem é ser capaz deste transfert num outro centro de perspectiva"(75). Claro que esta tradução não será nunca uma tradução integral, mas este pressuposto de que podemos ser competentes em várias culturas não significa que sejamos igualmente competentes em todas elas, residindo também a nossa singularidade nessa diferença de competências.

A partir destes pressupostos, penso ser possível enunciar alguns dos princípios nucleares para assumir, no actual contexto da globalização, a mestiçagem em profundidade como projecto de um autêntico diálogo intercultural.

O primeiro desses princípios tem a ver com o ethos libertador dos direitos humanos tal como eles são progressivamente consagrados a partir das memórias das vítimas da violência, da opressão, e da exclusão. Muitas têm sido as observações críticas às cartas de direitos humanos que pretendem enumerá-los de uma forma universal e atemporal, padecendo sempre tais enumerações das circunstâncias históricas, geográficas e culturais que constituem o quadro-base da sua enumeração.

(73) Cf. Thomas Kuhn, The Structure of Scientific Revolutions, Chicago, The University of Chicago Press, 1970, especialmente todo o capítulo X. Para o conceito de incomensurabilidade, cf. pp. 103, 148, 150 e 157.

(74) Cf. P. Feyerabend, Tratado contra o método, trad. port. de Miguel Serras Pereira, Lisboa, Relógio d'Água, 1993, cap. 16, especialmente pp. 275-285.

(75) P. Ricoeur, "Civilisation universelle et cultures nationales", pp. 298-299. 
Considerando tais observações minimamente pertinentes, pode concluir-se, com Dussel, que os direitos humanos "não podem ser contabilizados a priori", mas "são por natureza históricos", estruturando-se historicamente como "direitos vigentes" e sendo "postos em questão a partir da consciência ético-política dos 'novos' movimentos sociais que lutam pelo reconhecimento da sua dignidade negada"(76). Não implicando esta posição um relativismo total, não implica também um dogmatismo que poderia cair em qualquer etnocentrismo. Implica antes a consciência de que é o ethos libertador das lutas sociais das vítimas e dos oprimidos que constitui os direitos humanos no seu potencial dinâmico, tendo em conta que o que nessas lutas se põe em marcha é uma cultura universal da libertação humana ${ }^{(77)}$. Ora só um diálogo intercultural activo e crítico permite superar a tendência para o particularismo que traduziria em relativismo a cultura dos direitos humanos como também só ele permite superar a tendência para o dogmatismo, que estenderia direitos humanos na sua configuração histórico-cultural singular a toda a humanidade. Este potencial dinâmico do ethos libertador dos direitos humanos visto a partir da luta dos marginalizados, dos perseguidos, dos oprimidos e dos excluídos permite desenvolver uma dupla dimensão de auto e heterocrítica da parte dos povos e das culturas, condição indispensável para que o diálogo aconteça e se repercuta numa praxis de transformação.

O segundo princípio determinante de uma transformação do contacto entre culturas num verdadeiro diálogo intercultural diz respeito a uma concepção de universalidade construída a partir de baixo e que se constitui claramente como alternativa à concepção de universalidade inerente à globalização neoliberal que surge não apenas como uma construção de cima para baixo, mas, mais ainda, como uma construção imposta de cima para baixo. A grande diferença entre estas duas formas de entender a universalidade é esta: enquanto a segunda acaba por impor um determinado mundo, o mundo da tecnocultura que economicamente se globaliza, como o único mundo, a primeira propõe uma pluralidade de mundos reais $^{(78)}$ em que os sentidos circulam e em que o universal resulta de

(76) E. Dussel, Hacia una filosofía política crítica, p. 151.

(77) Cf. Raúl Fornet-Betancourt, Transformación intercultural de la filosofía, pp. 285-297.

(78) Cf. idem, ibidem, pp. 375-376. 
uma interaç̧ão que se opera na base. Não é, pois, um centro de decisão mais ou menos opaco nas suas formas de decisão que decide aquilo que se universaliza, mas são as propostas plurais que, num tecido comunicativo de interacção livre e solidária, se vão universalizando no diálogo entre culturas. O que significa, simultaneamente, que, no contexto de uma mestiçagem em profundidade, estamos perante uma concepção dialógica de universalidade e não perante uma concepção monológica, que será sempre etnocêntrica com a exclusão, visível ou invisível, de todas as singularidades que se situam na periferia. Esta concepção de universalidade implica também o reconhecimento de que, como diz Lamo de Espinosa, "o pluralismo é a nova forma do universalismo, um universalismo sem uniformidade"(79).

Recuperaria, em terceiro lugar, a centralidade, a incontornabilidade e a preservação do núcleo ético e mítico de cada cultura como forma de salvaguardar a sua singularidade, não num processo de afastamento chauvinista ou solipsista, mas numa aproximação dialógica com os outros. Tal núcleo, longe de exprimir um fechamento sobre si, implica, por tudo o que o envolve, uma abertura criadora ao mundo da alteridade. Com efeito, quando Paul Ricoeur procura esse núcleo, vê-se obrigado a passar sucessivamente pelos valores morais imediatos que configuram os costumes e as tradições de um povo (camada que já de si incorpora a relação e a interacção com os outros povos), pelas instituições tradicionais em que se vão cristalizando o pensamento, a vontade e os sentimentos de um grupo humano num dado momento da sua história (que é também e sempre uma história com os outros), para chegar à camada de imagens e símbolos que constituem as representações de base de um povo, que se situam a um nível inconsciente, e que, por se inscreverem no domínio do imaginário e do simbólico, estruturam as linguagens da superfície, mas, porque tal estruturação se caracteriza por um profundo dinamismo, não as estruturam de uma forma fechada ou fixista, mas de um modo tal que toda a tradição cultural se recria, a partir desse núcleo ético-mítico, de forma incessante e permanente ${ }^{(80)}$. Este núcleo ético e mítico,

(79) Emilio Lamo de Espinosa, "Fronteras culturales", p. 19.

(80) Cf. Paul Ricoeur, "Civilisation universelle et cultures nationales", pp. 294-297. 
pela sua concretização num fundo de imagens mas, simultaneamente, pelo impulso criador que o caracteriza, é a tradução prática da dialéctica entre fechamento e abertura, entre conservação e inovação, entre necessidade e liberdade que caracteriza toda a dinâmica cultural no cruzamento com outras tradições, igualmente singulares, igualmente conservadoras e igualmente criadoras ${ }^{(81)}$.

Em quarto lugar, parece-me indispensável cruzar a mestiçagem em profundidade enquanto diálogo intercultural com o exercício da Filosofia como ecosofia, que, a partir de uma ecofilia, se desenvolve numa necessária e imprescindível ecoética. Porque se a globalização de rapina assenta num projecto de domínio que, destruindo a casa das culturas, a sua morada física e terrena, destrói o seu mundo a partir de uma filosofia do progresso como exploração, instrumentalização e consumo, a universalização a partir de baixo, a mundialização assente na solidariedade, promove a atenção ao que no fundo do fundo de todos os povos constitui um apelo ao respeito pela vida na sua biodiversidade, na sua envolvência e na sua complexidade holística. Como refere Miguel Baptista Pereira, "em todas as tradições culturais e religiosas há princípios de sabedoria e atitudes basilares, em que se afirmam e promovem fundamentos naturais da vida", acrescentando, numa clara e explícita referência ao diálogo intercultural: "Nesta sequência, não há propriamente necessidade de um ethos mundial uniformizado mas de tradições múltiplas com a sua sabedoria da terra (Eco-sofia), o seu ethos eco-social e o seu amor telúrico (Eco-filia) ${ }^{\prime \prime(82)}$. Esta dinâmica filosófica exige, naturalmente, face à razão instrumental da tecnociência, uma razão pática ou sensível ${ }^{(83)}$, aberta ao

(81) "La création", dirá Paul Ricoeur, (ibidem, p. 297), "échappe à toute prévision, à toute planification, à toute décision d'un parti ou d'un Etat. L'artiste - pour le prendre comme le témoin de la création culturelle - n'exprime son peuple que s'il ne se le propose pas, et si nul ne lui commande".

(82) Cf. Miguel Baptista Pereira, "Alteridade, linguagem e globalização", p. 7.

(83) Cf. João Maria André, Pensamento e afectividade. Da paixão da razão às razões das paixões, Coimbra, Quarteto, 1999, em especial pp. 45-57 e pp. 123-136. Cf. também sobre a razão sensível e afectiva que, da experiência pática do sofrimento que o médico pode captar na sua relação com o doente, se transforma e eleva a paradigma de abertura ao mundo e à natureza, o texto de Miguel Baptista Pereira, num interessante diálogo entre V. von Weizsäcker, Heidegger e Gadamer, intitulado "Meditação filosófica e medicina", Revista Filosófica de Coimbra,vol. 21/XI, 2002, esp. pp. 35-36, onde se pode ler: "Aberta ao outro da 
mundo, na sua receptividade e afectividade perante a natureza e o outro, de modo a transformar o princípio da indiferença em princípio da responsabilidade e uma relação de exploração (quer dos outros, quer da natureza) em relação de solidariedade, já que "a Ética da Solidariedade Mundial tem por escopo assumir, de modo construtivo, as diferenças entre as culturas, a fim de desenvolver alternativas com êxito para além das perspectivas colhidas do modelo ocidental de bem-estar"(84).

Por último, acrescentaria a estes princípios para a activação da mestiçagem como diálogo intercultural um outro que constitui a sua base indispensável: o retorno ao berço natalício e a valorização da língua materna como fluxo de sentido em que se concretizou a nossa primeira abertura ao mundo, como leite em que se decantam as memórias de que se faz a nossa identidade, como fonte de que nos alimentamos no nosso encontro com os outros em outras tantas fontes ou nascentes e outros tantos rios de tradições culturais diferentes ${ }^{(85)}$. É na língua materna que o homem começa por se compreender e por se identificar, é na língua materna que o homem se capta, antes de mais, no seu enraizamento corpóreo e afectivo num mundo cultural e histórico, é no seio da língua materna que se percebe o sentido pleno do diálogo como jogo enquanto troca de experiências e memórias, sendo também através da língua materna que o homem resiste à uniformização cultural que, em tempos de globalização, se afirma como uma uniformização idiomática. A leitura da forma como se apresenta hoje o panorama das línguas nas redes conectivas de comunicação do Sistema-mundo é bem um sinal ou um sintoma do que pode ser a mestiçagem nos seus dois registos: à superfície ou em profundidade. Mestiçagem à superfície é a deturpação das línguas, a sua corrupção artificial e forçada pelo idioma praticamente único em que se circula nas auto-estradas da informação, a sua transformação num mosaico epidérmico de estrangeirismos, cuja origem e peso semântico se perde na velocidade e na leveza com que se realiza; mestiçagem em

compreensão transjectiva, ao ser da natureza relacionado com o outro, que ela não é, ao ser da vida em cuja corrente vivemos e da qual dependemos, está a nossa razão sensível e afectiva, cuja fraqueza esteve no esquecimento das suas raízes páticas".

(84) Cf. idem, "Alteridade, linguagem e globalização", p. 8.

(85) Para a importância da linguagem e para a valorização da língua materna em contexto de globalização, cf. idem, ibidem, sobretudo pp. 9-19 e 33-37. 
profundidade é a fecundação das línguas umas com as outras, o diálogo das suas memórias, a comunicação das suas fontes, a intercircularidade dos seus mundos, sem que isso desvirtue as identidades dinâmicas dos homens e dos povos nos seus encontros e desencontros com o tempo e com a história. Por isso, impõe-se que o diálogo intercultural comece por ser um regresso à linguagem, pois, como afirma Miguel Baptista Pereira, "regressar à linguagem é reconhecer a singularidade do berço e suas possibilidades, cuja realização futura terá sempre a urgência dos momentos únicos imposta pela inevitabilidade da morte num tempo irreversível." E acrescenta: "Pela linguagem vinda do berço manifesta-se o nosso ser, o dos outros e o do mundo, e, por isso, esta fenomenologia natalícia, linguisticamente mediada, é já ontologia inicial, que se deve aprofundar na história de cada um enquanto ser no mundo"(86). Neste aprofundamento do nosso ser-no-mundo como ser-com-os-outros-em-mundo se realiza e fecunda o nosso ser cultural num ser-com-as-outras-culturas em interacção dinâmica, aprendizagem recíproca e partilha de raízes, mundos e horizontes.

Assumida, assim, a mestiçagem como diálogo intercultural, não será difícil perceber que na concretização do seu projecto se integram três dimensões que devem ser vistas como indissociáveis, pois a falha de qualquer uma delas põe imediatamente em causa toda a sua configuração antropológica, ético-política e educativa: a vertente informativa, a vertente crítica e a vertente praxística e transformadora. Pela vertente informativa postula-se, como momento indispensável do diálogo intercultural, o conhecimento do outro, da sua cultura, das suas tradições e também o conhecimento da sua língua, da sua história e do seu enraizamento histórico-geográfico. Pressupor que o diálogo se pode realizar sem que haja informação sobre quem é e o que é aquele com quem dialogamos é reduzir o outro a um mero marco na nossa caminhada, é descorporalizá-lo e descontextualizá-lo, é assumir o encontro como um movimento unidireccional, fechando desse modo as portas a um diálogo autêntico e verdadeiro com a sua transformação num monólogo. Por isso, em tempos de mestiçagem e de multiculturalismo, esta vertente informativa tem de ser exercida em todos os sentidos, o que significa que deve criar as condições para que todos aqueles que convivem em espaços multiculturais se conheçam mutuamente, não bastando proporcionar

(86) Idem, ibidem, p. 37. 
às culturas minoritárias elementos informativos para superarem os seus déficits no seio das culturas maioritárias em que estão inseridas. É por isso que modelos de educação intercultural como os assimilacionistas, compensatórios ou segregacionistas ${ }^{(87)}$, voltados exclusivamente para a equalização das oportunidades educativas ou para um mero conhecimento da diferença ${ }^{(88)}$ ou como os modelos tecnológico-positivistas desenhados por peritos da ciência da educação para compensar deficiências escolares de minorias étnicas ${ }^{(89)}$, ou mesmo os modelos de orientação simplesmente pluralista, tendentes a preservar e a estender o pluralismo ${ }^{(90)}$ dando informação e uma certa competência hermenêutica sobre todas as culturas em jogo ${ }^{(91)}$, podendo, nestes últimos casos, significar um passo para a aproximação, não constituem ainda uma verdadeira concretização do diálogo intercultural. O desenvolvimento de uma consciência crítica face às situações de injustiça e às suas causas, àquilo que perverte um igual acesso ao exercício do direito de cidadania, não só política mas também cultural, abre uma vertente que constitui já o chão indispensável para um diálogo intercultural despreconceituoso e empenhado. Mas se se assume esse diálogo com toda a sua radicalidade ele implica muito mais: uma praxis de transformação interior que se repercute numa praxis de transformação social de todas as situações que geram vítimas e excluídos do universo cultural e político dominante e maioritário. É por isso que a educação intercultural pode e deve ser assumida como uma prática de transformação e reconstrução social ${ }^{(92)}$, num empenhamento

(87) Cf. Marta Sabariego, La educación intercultural ante los retos del siglo XXI, Bilbao, Desclée de Brouwer, 2002, pp. 79-84.

(88) Veja-se uma exposição destes modelos, com origens, desenhos e objectivos muito diversos, em F. Javier García Castaño, Rafael A. Pulido Moyano e Ángel Montes del Castillo, "La educación multicultural y el concepto de cultura", pp. 50-54.

(89) Para uma crítica a estes modelos, cf. A García Martínez e J. Saéz Carreras, Del racismo a la interculturalidad. Competencia de la educación, Madrid, Narcea, 1998, pp. 128-133.

(90) F. Javier García Castaño, Rafael A. Pulido Moyano e Ángel Montes del Castillo, "La educación multicultural y el concepto de cultura", pp. 50-54 e 55-56.

(91) Cf. a caracterização do modelo hermenêutico ou interpretativo feita por García Martínez e Sáez Carreras, ob. cit., pp. 133-136.

(92) F. Javier García Castaño, Rafael A. Pulido Moyano e Ángel Montes del Castillo, "La educación multicultural y el concepto de cultura", pp. 50-54, pp. 59-60. 
sócio-político ${ }^{(93)}$, numa perspectiva holística e como educação para a cidadania plena ${ }^{(94)}$.

Com tudo isto é a própria filosofia que se vê em processo de transformação com o diálogo intercultural e, por isso, não é de estranhar que se fala não só da transformação intercultural da filosofia, título da obra de um autor já diversas vezes referido ao longo deste texto ${ }^{(95)}$, mas inclusivamente de "filosofia intercultural", num movimento que ganha forma não só na América Latina, na África e na Ásia, mas também na Europa, onde encontra já inclusivamente expressão numa série dedicada aos respectivos problemas ${ }^{(96)}$. Enfrentar a questão da construção desta nova filosofia intercultural, na sua pluralidade constitutiva e na sua intrínseca dimensão dialógica é o desafio que, em sede filosófica, se nos levanta como resposta às consequências de uma globalização homogeneizante ou de uma mestiçagem meramente epidérmica.

\section{Nota final}

Este percurso pela globalização, pelo multiculturalismo, pela mestiçagem e pelo diálogo intercultural, com todas as suas implicações epistemológicas, antropológicas, políticas, culturais e educativas, mostrou-nos que não há respostas lineares aos problemas da sociedade actual e que fenómenos, aparentemente simples, comportam implicações

(93) Cf. García Martínez e Sáez Carreras, ob. cit., pp. 136-141.

(94) Cf. J. A. Banks, Educating citizens in a Multicultural Society, New York, Teachers, College Press, 1997. Cf. também Marta Sabariego, ob. cit., pp. 97-129.

(95) Cf. Raúl Fornet-Betancourt, Transformación intercultural de la filosofia, especialmente o Cap. I da $2^{a}$ parte, intitulado "Aprender a filosofar desde el contexto del diálogo de las culturas" (pp. 173-189).

(96) Referimo-nos à série "Studien zur interkulturellen Philosophie", publicada pelas edições Rodopi de Amesterdão, sob coordenação de Heinz Kimmerle e Ram Adhar Mall. Veja-se especialmente, do volume dirigido por R. A. Mall e D. Lohmar, Philosophische Grundlagen der Interkulturalität, Amsterdam, Editions Rodopi, 1993, o texto programático de R. A Mall, "Begriff, Inhalt, Methode und Hermenutik der interkulturellen Philosophie", pp. 1-27, que apresenta alguns contornos programáticos e metodológicos desta nova filosofia intercultural e o de Franz Martin Wimmer, "Ansätze einer interkulturellen Philosophie", pp. 29-40 , que, em seis teses, sintetiza os seus princípios mais significativos. 
que reclamam e mobilizam o fundo do nosso ser em todas as suas dimensões. Trata-se de criar "espaços utópicos de mediação e mestiçagem", mostrando a força da utopia como "alternativa e ruptura" capaz de uma praxis transformadora que já se tem vindo a afirmar na América Latina e que pode constituir-se como luz de esperança para o resto do mundo ${ }^{(97)}$.

Nesse contexto utópico, só uma razão pática pode corresponder à solicitação do outro que nos chega de um mundo diferente, com a sua cultura, os seus valores e a sua memória de mundo, e, por isso, a atitude que uma mestiçagem em profundidade reclama é a de uma capacidade de acolhimento do outro, transformando em hóspede o que atitudes xenófobas vêem apenas como hostil, termos que têm uma raiz comum mas que traduzem comportamentos opostos ${ }^{(98)}$. Exercer o diálogo como hospedagem é ligar-me afectivamente ao outro e deixar que ele se ligue a mim, acolher-me no seu seio como se fosse minha habitação ou morada e deixar que ele nos more ou habite como se fosse a sua casa. Todavia, é necessário ter presente que a relação com o outro em que moramos ou que em nós mora não é uma mera relação extrínseca e estática, como se morar fosse apenas o estar em, tal como um livro está numa estante ou um objecto num armário, mas é uma relação de mútua transformação dialógica numa comunicação livre e intersubjectiva. Esta noção de diálogo intercultural como hospedagem remete para o conceito de tolerância que, num dos seus sentidos etimológicos, implica a capacidade de acolher e levar connosco o outro com quem nos encontramos ou a disposição de um sistema que, para "aceitar na sua economia aquele que lhe é estrangeiro, deve, em certa medida, reorganizar-se interiormente" ${ }^{\prime \prime 99)}$. O diálogo intercultural supõe, assim, a metanóia, no seu sentido mais profundo, recuperando simultaneamente a noção aristotélica de que o nous é capax mundi, capax universi, e que na sua reformulação, por inspiração dos escritos herméticos, no motivo do homem como

(97) Cf. Fernando Aínsa, "El destino de la utopía latinoamericana como interculturalidad y mestizaje", in Raúl Fornet-Betancourt (Ed.), Culturas y Poder, pp. 279-297.

(98) Cf. Miguel Baptista Pereira, "Alteridade, linguagem e globalização", p. 18.

(99) H. Giannini, "Accueillir l'étrangeté", in Claude Sahel (Ed.), La tolérance. Pour un humanisme hérétique, Paris, Éditions Autrement, 1991, p. 19. Cf. também João Maria André, Pensamento e afectividade, pp. 128-130. 
microcosmo, sobretudo nos autores neoplatónicos renascentistas, aponta já para a capacidade de o homem ser, não apenas em termos cognitivos, mas no mais íntimo do seu ser e da sua liberdade, o universo, ou seja, a unidade da diversidade de todas as coisas ${ }^{(100)}$.

Mestiçagem e diálogo intercultural cruzariam assim o fenómeno da mundialização ou da globalização assumindo as dimensões positivas que o conceito de universo lhes proporciona, reencontrando simultaneamente os fios do símbolo do microcosmo que outro momento da globalização, o Renascimento dos séculos XV e XVI, deixou ao pensamento filosófico numa abertura à totalidade, num reconhecimento da unidade na riqueza e fecundidade da diferença que a constitui e numa inequívoca afirmação da liberdade assumida como a marca distintiva e inalienável de ser homem.

Paradela da Cortiça, Março de 2004

${ }^{(100)}$ Sobre a noção dinâmica de microcosmo a partir de alguns autores do Renascimento e sobre as suas implicações éticas, cf. João Maria André, "O homem como microcosmo: da concepção dinâmica do homem em Nicolau de Cusa à inflexão espiritualista da antropologia de Ficino", Philosophica, vol. 14, 1999, pp. 7-30. 